\title{
The influence of chemical composition and mixing state of Los Angeles urban aerosol on CCN number and cloud properties
}

\author{
M. J. Cubison ${ }^{1}$, B. Ervens ${ }^{1,2,3}$, G. Feingold ${ }^{3}$, K. S. Docherty ${ }^{1}$, I. M. Ulbrich $^{1,4}$, L. Shields ${ }^{5}$, K. Prather ${ }^{5}$, S. Hering ${ }^{6}$, \\ and J. L. Jimenez ${ }^{1,4}$ \\ ${ }^{1}$ Cooperative Institute for Research in the Environmental Sciences (CIRES), University of Colorado, Boulder, CO, USA \\ ${ }^{2}$ Atmospheric Science Department, Colorado State University, Fort Collins, CO, USA \\ ${ }^{3}$ NOAA Earth System Research Laboratory, Boulder, CO, USA \\ ${ }^{4}$ Dept. of Chemistry and Biochemistry, University of Colorado, Boulder, CO, USA \\ ${ }^{5}$ University of California at San Diego, CA, USA \\ ${ }^{6}$ Aerosol Dynamics, Inc., Berkeley, CA, USA
}

Received: 31 January 2008 - Published in Atmos. Chem. Phys. Discuss.: 18 March 2008

Revised: 24 June 2008 - Accepted: 21 August 2008 - Published: 26 September 2008

\begin{abstract}
The relationship between cloud condensation nuclei $(\mathrm{CCN})$ number and the physical and chemical properties of the atmospheric aerosol distribution is explored for a polluted urban data set from the Study of Organic Aerosols at Riverside I (SOAR-1) campaign conducted at Riverside, California, USA during summer 2005. The mixing state and, to a lesser degree, the average chemical composition are shown to be important parameters in determining the activation properties of those particles around the critical activation diameters for atmospherically-realistic supersaturation values. Closure between predictions and measurements of $\mathrm{CCN}$ number at several supersaturations is attempted by modeling a number of aerosol chemical composition and mixing state cases of increasing complexity. It is shown that a realistic treatment of the state of mixing of the urban aerosol distribution is critical in order to eliminate model bias. Fresh emissions such as elemental carbon and small organic particles must be treated as non-activating and explicitly accounted for in the model. The relative number concentration of these particles compared to inorganics and oxygenated organic compounds of limited hygroscopicity plays an important role in determining the $\mathrm{CCN}$ number. Furthermore, expanding the different composition/mixing state cases to predictions of cloud droplet number concentration in a cloud parcel model highlights the dependence of cloud optical properties on the state of mixing and hygroscopic properties of the different
\end{abstract}

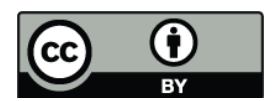

Correspondence to: J. L. Jimenez (jose.jimenez@colorado.edu) aerosol modes, but shows that the relative differences between the different cases are reduced compared to those from the $\mathrm{CCN}$ model.

\section{Introduction}

The indirect influence of aerosol particles on the radiative balance of the atmosphere through changes in cloud droplet number $\left(N_{d}\right)$ and persistence of clouds, known as the "aerosol indirect effect" (Twomey, 1974; Albrecht, 1989), carries the largest uncertainty amongst the presently known causes of radiative forcing (IPCC, 2001, 2007). McFiggans et al. (2005) review much of the recent investigative work aiming to better characterise the physical and chemical parameters determining the relationship between the aerosol size distribution and chemical composition and cloud condensation nuclei $(\mathrm{CCN})$. Whilst much progress is reported on our understanding of activation processes, McFiggans et al. outline measurement requirements which would further this knowledge, principally details of the physical and chemical nature of Aitken and small-accumulation mode aerosol in tandem with measurements of the CCN activation spectrum.

Recent CCN studies reported in the literature have addressed the relative importance of the size distribution, particle composition and mixing state in determining $\mathrm{CCN}$ activation, but there is disagreement on the relative importance of these parameters (Roberts et al., 2002; Feingold, 2003; Ervens et al., 2005; Mircea et al., 2005; Dusek et al., 2006a;

Published by Copernicus Publications on behalf of the European Geosciences Union. 
Anttila and Kerminen, 2007; Hudson, 2007; Quinn et al., 2007). CCN closure studies are a useful approach to test our knowledge of the controlling physical and chemical properties and help verify experimental results. Several closure studies are reported in the literature where $\mathrm{CCN}$ activation measurements are compared with the output from equilibrium models which use Köhler theory to predict the $\mathrm{CCN}$ number concentration, $N_{\mathrm{CCN}}$, from measured aerosol properties such as size distribution and composition or hygroscopicity. In the background atmosphere, several studies have been able to show closure between the measured and modelled results (Chuang et al., 2000; Dusek et al., 2003; VanReken et al., 2003; Rissler et al., 2004; Gasparini et al., 2006; Stroud et al., 2007). However, the particle distribution is more complex in locations such as urban areas where an air mass may comprise several different externally-mixed components, each exhibiting different chemical and physical characteristics (Lee et al., 2003; Alfarra et al., 2004; Zhang et al., 2004a; Salcedo et al., 2006). Some components are shown to exhibit reduced activation properties with respect to inorganic salts, such as biomass burning plumes (Mircea et al., 2005; Lee et al., 2006; Clarke et al., 2007), humic-like substances (Dinar et al., 2006), secondary organics formed from oxidation of common biogenic emissions such as monoterpenes (VanReken et al., 2005; Varutbangkul et al., 2006) and black carbon (Dusek et al., 2006b; Kuwata et al., 2007). Other organic components are shown to activate more easily than their solubility might suggest (Raymond and Pandis, 2002; Hartz et al., 2006), but still much less than inorganic species. Particles that are generally hydrophobic or only slightly hygroscopic in nature are observed to significantly impact CCN properties of the atmosphere (Roberts et al., 2003; Roberts et al., 2006), and for internally mixed particles it appears that the moles of insoluble material is the most important chemical parameter affecting aerosol water affinity in the sub- (McFiggans et al., 2005) and supersaturated (Rissler et al., 2004; Ervens et al., 2007) regimes. In an urban area, where many such components may be externally- or internally-mixed with hygroscopic inorganic aerosol, modelling the $\mathrm{CCN}$ activation from basic physical properties is more difficult. Further information about the nature of the particles, such as size-resolved chemical composition or detailed properties of the organic component, may be required in order to successfully predict the $\mathrm{CCN}$ activation (Broekhuizen et al., 2006; Mochida et al., 2006; Quinn et al., 2007). Furthermore, recent work using data collected from areas under the influence of recent anthropogenic emissions has concluded that mixing state needs to be considered in order to resolve bias in the model predictions of $N_{\mathrm{CCN}}$. Medina et al. (2007) conclude that an assumption of internal mixing in a $\mathrm{CCN}$ model considering size-resolved composition is responsible for a $\sim 36 \%$ over-prediction of $N_{\mathrm{CCN}}$ as compared to measurements of polluted continental or semi-urban air masses in New Hampshire. Sensitivity studies on data collected at the Duke Forest site in North Carolina, showed that model predictions were highly sensitive to the assumed mixing state of the aerosol size distribution modes used for size distribution input, but lack of mixing state measurements precluded a quantitative evaluation of the effect of this parameter on closure (Stroud et al., 2007). Parameterisation of the mixing state of urban aerosol modes and their hygroscopic parameters has also been recently shown as important with respect to interpreting satellite retrieval data on urban aerosols (Wang and Martin, 2007).

Whilst aerosol-CCN closure studies improve our understanding of the importance of physical and chemical properties for aerosol activation, they only refer to equilibrium conditions at one (or several) constant supersaturations, and thus neglect feedbacks on supersaturation and drop growth due to dynamic processes in clouds, which often dampen the effects of variations in CCN number. In a recent cloud model study, it was shown that composition only has a significant effect on cloud drop number concentration for an internally mixed aerosol population when competition for water is strong, i.e. at low updrafts, and/or high particle concentrations (Ervens et al., 2005). However, the role of the mixing state of aerosol was neglected in that study. Recent work shows that the uncertainty in predicting cloud droplet number $\left(N_{d}\right)$ can be related to the uncertainty in $N_{\mathrm{CCN}}$ over a wide range of cloud microphysical conditions (Sotiropoulou et al., 2006). However, it has been shown that the relationship that is predicted between $N_{\mathrm{CCN}}$ and aerosol number concentration $\left(N_{a}\right)$ often cannot be extrapolated to a relationship between $N_{\mathrm{CCN}}$ and $N_{d}$ because the drop number concentration is influenced by updraft velocity $(w)$ and shape of the aerosol size distribution (Warner, 1969; Twomey, 1977).

Twomey's definition of the first indirect effect predicts a relationship between a change in the cloud droplet radius and cloud albedo with a change in aerosol number concentration for a constant liquid water content (Twomey, 1991). In the more general case, changes in water content and shape of the cloud droplet distribution should also be considered in order to evaluate the effect of aerosols on cloud microphysics and optical properties. It has been shown that when droplet distribution broadening is associated with an increase in drop concentration, the predicted Twomey effect is reduced (Liu and Daum, 2002). Conversely, when broadening accompanies decreases in drop concentration (e.g., via collisioncoalescence), the Twomey effect is enhanced (Feingold et al., 1997).

The study of aerosol-CCN and aerosol- $N_{d}$ closure and relationships inside and in the near-field outflow of large urban areas is of interest for two main reasons: (a) as the locus of intense primary particle emissions for a variety of sources which are often gradually internally mixed during the day due to coagulation and condensation of secondary species (from intense local emissions of secondary precursors), urban areas present one of the most challenging cases to test our understanding of the parameters controlling droplet activation and growth. Furthermore, recent work has shown 
that the principal uncertainty in predicting the magnitude of the global aerosol indirect effect arises from regions where the atmosphere is under the influence of urban emissions (Sotiropoulou et al., 2007); (b) at present more than 50\% of the world population lives in urban areas and this fraction is growing, including numerous megacities, and thus the fraction of the polluted regions affected by urban aerosols (with atmospheric aging times $\leq 1$ day) is non-negligible and growing rapidly (Molina et al., 2007).

In this study, we present results from the Study of Organic Aerosols at Riverside (SOAR-1) campaign held in Riverside, California, during July and August of 2005, a polluted area within the Los Angeles megacity. Riverside experiences both fresh emissions and the advection of urban aerosols with atmospheric ages of $\sim 1-2$ days, and thus is a good location to study the aerosol properties encountered inside and in the near-field outflow of megacities. We investigate the diurnal cycles of urban aerosol and $\mathrm{CCN}$ and use an activation model to probe the influences of size distribution, chemical composition, and mixing state on $\mathrm{CCN}$. We use a $\mathrm{CCN}$ model employing increasingly complex cases of composition and mixing state, which highlight the importance of the mixing state of the various aerosol species. In addition to $\mathrm{CCN}$ predictions, we use these approaches as input data for a cloud model that we initialize with the measured size distributions and the different cases of composition and mixing state that are used to predict $\mathrm{CCN}$ number concentrations. We use the cloud model results to evaluate the extent to which the impact on $\mathrm{CCN}$ arising from differences in aerosol composition and mixing state typical of an urban area can affect cloud droplet concentrations and cloud optical properties.

\section{Experimental description}

The city of Riverside lies about $80 \mathrm{~km}$ east of the Pacific coast on the eastern edge of the Los Angeles (LA) - San Bernardino-Riverside conurbation, population 18 million. The prevailing westerly winds advect the accumulated pollution from the densely populated coastal and downtown LA areas and upwind farmlands eastwards towards Riverside. During this process, the pollution is largely confined to the LA basin by inversions which cap the highly polluted boundary layer air within the surrounding topography. The SOAR1 campaign, conducted between 16 July and 15 August 2005, sampled at a location on the University of California at Riverside campus, about $1 \mathrm{~km}$ east of Highway 60 carrying commuting traffic to the LA area. The meteorological conditions during the summer campaign were very consistent, with a clear diurnal cycle, low cloud cover and temperatures generally peaking around 35 to $40^{\circ} \mathrm{C}$ in the afternoon and reaching a low of 15 to $20^{\circ} \mathrm{C}$ in the early morning. The location and weather conditions combine to produce a very polluted atmosphere consisting of a complex mixture of locally-emitted traffic emissions combined with high advected levels of primary and secondary aerosols.

The aerosol inlet was approximately $7 \mathrm{~m}$ above ground level. A bypass flow was used to facilitate the use of a $2.5 \mu \mathrm{m}$ cut-off cyclone designed for a $10 \mathrm{lpm}$ flow rate (URG-2000-30EN, www.urgcorp.com/cyclones) on the inlet and minimize losses in the line. The inlet flow was dried using either Nafion driers (PermaPure PD Series, www. permapure.com) or silica gel diffusion dryers before passing through Y stainless steel flow splitters (Brechtel Manufacturing, Inc., www.brechtel.com) for analysis by the various instruments. The aerosol size distribution was measured from $3 \mathrm{~nm}$ to $32 \mu \mathrm{m}$ using a combination of two Scanning Mobility Particle Sizer systems (SMPS, TSI Model 3080, www.tsi.com) and an Optical Particle Counter (OPC, Grimm Model 1.110, www.grimm-aerosol.com). A time series of particle effective density was available for the latter stage of the campaign from the combination of an SMPS system with the Aerosol Particle Mass Analyser (APM, Kanomax, www.kanomax-usa.com) (McMurry et al., 2002). Elemental carbon (EC) and organic carbon (OC) mass measurements were available from the commercially available Sunset Labs Semi-Continuous EC/OC Analyzer (www.sunlab.com) (Snyder and Schauer, 2007).

Size-resolved chemical composition information was available from an Aerodyne Time-of-Flight Aerosol Mass Spectrometer (ToF-AMS) (Drewnick et al., 2005; DeCarlo et al., 2006). The AMS uses an aerodynamic lens (Zhang et al., 2004b) to focus particles into a particle time-of-flight chamber to separate aerosol according to their vacuum aerodynamic diameter and flash vapourise them under high vacuum, ionise the vapors by electron impact, and analyse the ions with a time-of-flight mass spectrometer. The mass spectrum is used to determine the mass loadings of several chemical species or groups of species (Allan et al., 2004), size segregated in the range of approximately $35 \mathrm{~nm}$ to $1 \mu \mathrm{m}$. In addition, size-resolved single-particle chemical composition was also acquired with a Aerosol Time-Of-Flight MassSpectrometer (ATOFMS) (Noble and Prather, 1996). This version of the ATOFMS uses a similar aerodynamic lens inlet as the AMS, but employs dual timing lasers to determine the arrival of single particles into a the focus point of a NdYAG laser which desorbs and ionises particle constituents into both positive and negative ions, which are analysed by dual time-of-flight mass spectrometers. Both instruments measure the size-resolved chemical composition according to vacuum aerodynamic diameter, $d_{v a}$, defined in DeCarlo et al. (2004). A comparison and discussion of the ATOFMS, AMS, and two other laser ablation instruments is given by Middlebrook et al. (2003). The combination of the two provides an extensive data set including both quantitative sizeresolved chemical information and a direct determination of the mixing state of the aerosol from single particle analysis.

The CCN activation properties of the aerosol ensemble were measured at various different supersaturations using the 


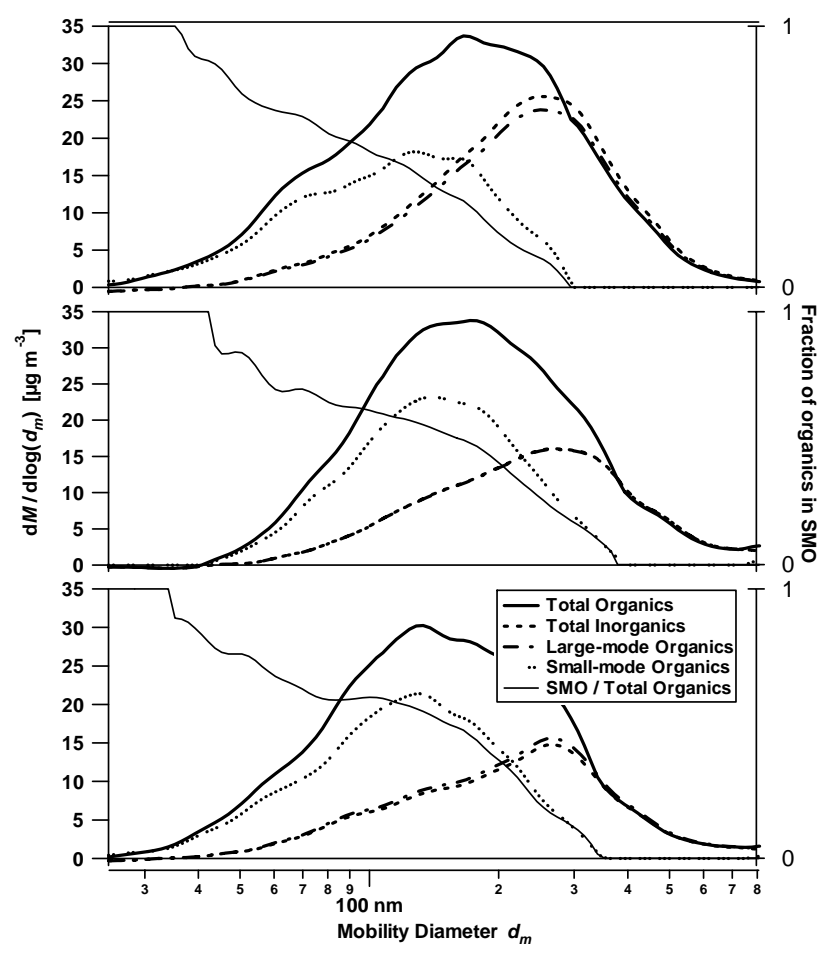

Fig. 1. Size resolved mass loadings from the AMS averaged for weekdays over the periods 06:00-07:00 $\mathrm{h}$ (top), 12:00-13:00 $\mathrm{h}$ (center) and 18:00-19:00 h (bottom) The relative fractions of the inorganics to organics in the large-diameter internally-mixed mode are used to determine the assumed externally-mixed small mode organics. A more thorough explanation is given in the text. The size-resolved fraction of the organics calculated in the SMO is also shown. Although this does not change much over the diurnal cycle, there is more mass at the smaller diameters during the morning rush-hour period.

Continuous Flow Streamwise Thermal Gradient CCN Chamber (Droplet Measurement Technologies, Boulder, CO, USA, www.dropletmeasurement.com) (Roberts and Nenes, 2005; Lance et al., 2006). This new CCN instrument has greatly facilitated $\mathrm{CCN}$ research by providing a rapid, precise, and stable continuous flow instrument that is commercially available and that can be interfaced to other continuous flow instruments. During the SOAR-1 campaign the instrument was set up to record CCN activation at supersaturation set points of $S=0.1,0.3,0.5,0.7$ and $0.9 \%$ at 30 -min intervals. The actual operational supersaturation in the instrument was calculated from the instrument temperature and flow readings using the model of Lance et al. (2006), and used in custom software to analyse the flow rate, temperature and pressure variations within the instrument and thus eliminate errant readings such as those during unstable or rapidly changing conditions.

\section{Methods}

To investigate the relative importance of the physical and chemical characteristics and the mixing state of the aerosol on their $\mathrm{CCN}$ activation properties, the $\mathrm{CCN}$ model described by Ervens et al. (2007) was used to predict the CCN activation for comparison to the measurements from the $\mathrm{CCN}$ chamber using a number of different composition and mixing state cases. The model considers particles consisting of an internal mixture of very hygroscopic material, with the properties of ammonium sulphate, with a less-hygroscopic organic component. A further completely non-activating component, which is externally mixed with respect to the organic and ammonium sulphate particles, can also be introduced into the model cases. The CCN activation is calculated at the modeled supersaturation in the $\mathrm{CCN}$ chamber rather than the nominal set point values.

The hygroscopicity and $\mathrm{CCN}$ activity of the individual model components (i) can be summarized by considering a single parameter, $\kappa$ (Petters and Kreidenweis, 2007):

$\kappa=M_{w} / \rho_{w} \Sigma\left(v_{i} \Phi_{i} / M_{s i} \rho_{s i}\right)$

where $v$ is the number of molecules or ions a salt in solution dissociates into, $\Phi$ is the osmotic coefficient, $M_{w}$ and $M_{s}$ are the molecular weight of water and the solute, and $\rho_{w}$ and $\rho_{s}$ are the density of water and the solute respectively. Using this representation, it is shown that the relationship between the critical supersaturation and diameter can be defined using the $\kappa$ parameter, with highly soluble materials exhibiting $\kappa$ values around unity. Moderately hygroscopic organic species such as levoglucosan and malonic acid are shown to have $\kappa$ values in the range 0.01 to 0.5 , whilst hydrophobic particles would exhibit $\kappa$ values approaching zero (Petters and Kreidenweis, 2007). Hygroscopicity or CCN measurements of various secondary organic aerosol (SOA) compounds formed atmospheric simulation chambers give derived $\kappa$ values of around 0.06 to 0.2 (VanReken et al., 2005; Varutbangkul et al., 2006; Prenni et al., 2007), whereas oxidised primary organics have $\kappa$ values of around 0.01 or less (Petters et al., 2006). We thus use $\kappa$ values for our base case model of $\sim 0.5$ (ammonium sulphate) for the inorganic fraction and $\sim 0.01$ for the organic fraction. The sensitivity of the model to increasing the hygroscopicity of the organics is later studied. Although it was observed during the SOAR-1 campaign that the nitrate mass concentrations were broadly similar to the sulphate, use of the model components described above is consistent with earlier work (Koehler et al., 2006; Ervens et al., 2007), and unlikely to introduce much error as ammonium nitrate is also a soluble compound with a propensity to readily form $\mathrm{CCN}$. It has a $\kappa$ value of 0.78 , similar to ammonium sulphate (Petters and Kreidenweis, 2007), thus the activation diameters do not vary greatly $(47 \mathrm{~nm}$ as compared to $42 \mathrm{~nm}$ for $S=0.5 \%$ ). Hence the two compounds are interchangeable in the model calculations, to good accuracy. 
In all model variants, the SMPS size distribution and AMS chemical composition measurements provided the basis for the model calculations. Several different composition modes were determined using the mass spectrometers for input to the CCN model. In the urban atmosphere, small mode organic (SMO) particles are often observed with the AMS and other techniques, which many studies have shown are typically externally-mixed with respect to a more aged, larger diameter internally-mixed mode of organics and inorganics (Lee et al., 2002; Alfarra et al., 2004; Zhang et al., 2004a, 2007; Bein et al., 2005; Tolocka et al., 2005; Murphy et al., 2006; Niemi et al., 2006; Salcedo et al., 2006; Molina et al., 2007). If the larger-diameter accumulation mode is assumed to maintain a consistent composition across its size range (due to its longer "integration time" for atmospheric aging), then the organic/inorganic ratio for this entire mode can be estimated as the measured ratio at the larger diameters where there is no influence from smaller, externally mixed modes in the size distribution. The SMO mass concentration can then be calculated by subtracting the accumulation-mode organic size distribution estimated in this manner from the total measured organics, as demonstrated in Fig. 1. As expected, the SMO mass is significant at small diameters and falls to zero at $d_{v a} \sim 300-400 \mathrm{~nm}$. These mass loadings are converted to mobility space for direct comparison to the SMPS and input to the model using measured values of the particle effective density, using diurnal cycle measurements taken using the DMA-ATOFMS technique (Spencer et al., 2007) and from APM measurements in the work of Geller et al. (2006). The effective density of dry particles can also be estimated from the particle composition using estimated values for the different particle components. It is noted that these different techniques for calculating the particle effective densities have different dependencies on the particle morphology (DeCarlo et al., 2004), although they return similar results, with values around 1.2 to $1.4 \mathrm{~g} \mathrm{~cm}^{-3}$ for accumulation mode particles.

The SMO mass in urban areas can be further resolved into several components using factor analysis of the AMS mass spectra. Components such as hydrocarbon-like organic (HOA) and several types of oxygenated organic aerosol (OOA) (Zhang et al., 2005a; Ulbrich, 2006; Lanz et al., 2007; Ulbrich et al., 2008) are extracted, and they allow the introduction of further complexity into the compositional data in the model. The HOA fraction is assumed to represent fresh, carbonaceous traffic and other combustion emissions and was shown by Quinn et al. (2007) to be an important parameter influencing $\mathrm{CCN}$ activation in urban plumes measured over Houston, Texas. On the other hand, OOA is thought to be representative of local or regional SOA (Zhang et al., 2005c; Ulbrich, 2006; Lanz et al., 2007; Zhang et al., 2007). Similar to the observations of Zhang et al. (2005b) in Pittsburgh, a diurnal cycle was observed in the HOA and OOA fractions during the SOAR-1 campaign (Docherty et al., 2008). The fraction of the SMO mass resolved as HOA was highest in the morning when the site was under the great-

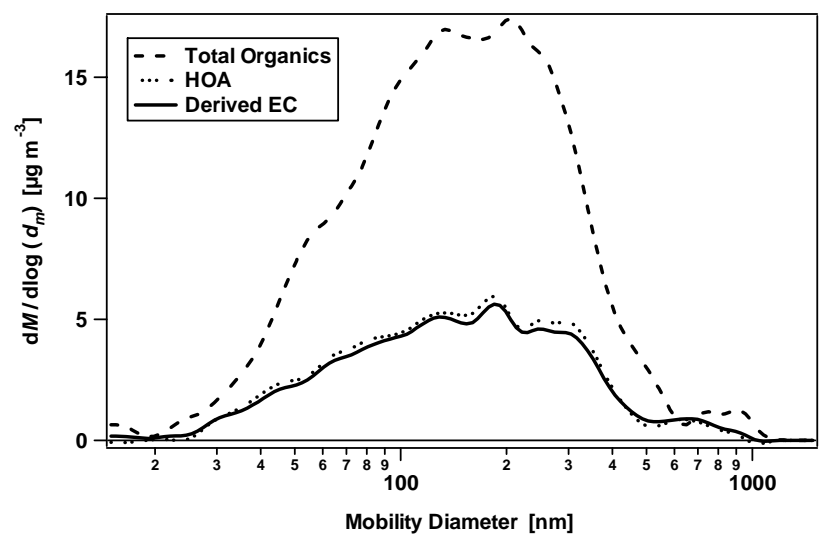

Fig. 2. Size-resolved mass loadings of the organics, HydrocarbonLike Organic Aerosol (HOA) and derived elemental carbon (EC, see methodology in text) for a weekday average from 06:00 to 07:00 h.

est influence from fresh traffic emissions. The OOA fraction dominated in the afternoon as photochemically-aged air was advected to the site from the Los Angeles basin. Biomass burning made a negligible contribution to particle concentrations during the SOAR-1 period, based on low satellite fire counts, and chemical markers from the AMS, ATOFMS and GC-MS analysis (Docherty et al., 2008).

There are two important classes of atmospheric aerosol that are not measured using the AMS. First, dust particles, which are often observed over Riverside with its location west of a large desert region. However, during the SOAR-1 study the winds were not favourable for the advection of dust to the sampling site and this aerosol component was not a significant feature of the aerosol distribution (Spencer et al., 2007). Second, elemental carbon (EC) particles are also not measured using the AMS (although non-refractory components internally mixed with them are (Slowik et al., 2004)), thus the methodology of Zhang et al. (2005b) was employed to infer the size distribution of black carbon by scaling the measurements of total EC mass to the observed HOA size distribution. A relationship is first derived between the observed HOA and EC mass; a regression line is calculated and then used to scale the HOA distribution to produce an estimated EC mass size distribution. In this case the HOA size distribution was calculated following the methodology of Zhang et al. (2005c), by subtracting $2 \%$ of the integrated signal at $\mathrm{m} / \mathrm{z}, 44$ from the integrated signal at $\mathrm{m} / \mathrm{z} 57$ (to account for interferences from OOA in the mass spectra) and normalizing to the bulk HOA measurement. Figure 2 shows the resulting size distributions of the weekday average from 06:00-07:00 $\mathrm{h}$ of the organic mass fraction, HOA and estimated EC. The EC distribution is very similar to that of the HOA, but similarly represents a small fraction of the particle mass.

The diurnal cycle for the measured $\mathrm{CCN}$ activated fractions at various supersaturations, the HOA and SMO mass 
Table 1. Summary of the different models used in the CCN predictions. Note that in models 4 and 5, some of the hydrocarbon-like organic aerosol (HOA) is incorporated in the small-mode organics (SMO), see Fig. 4 for more detail. Estimated elemental carbon is treated as an additional externally-mixed and non-activating component in $\mathrm{C} 3-5$.

\begin{tabular}{ccccc}
\hline Model Case & $\begin{array}{c}\text { Size-Resolved } \\
\text { Composition }\end{array}$ & Large-Mode Org. (LMO) & State of mixing, with respect to the large-mode inorganics $\kappa=0.5$ \\
Small-Mode Org. (SMO) & Hydrocarbon-Like Organics (HOA) \\
\hline 1 & No & & Internal, $\kappa=0.01$ \\
2 & Yes & External, Non-Activating \\
Internal, $\kappa=0.01$ & \\
4 & Yes & Internal, $\kappa=0.01$ & External, Non-Actv & Internal, $\kappa=0.01^{\mathrm{a}}$ \\
5 & Yes & Internal, $\kappa=0.01$ & Internal, $\kappa=0.01^{\mathrm{b}}$ & External, Non-Actv \\
\hline
\end{tabular}

${ }^{\mathrm{a}}$ If not part of SMO. ${ }^{\mathrm{b}}$ If not part of the HOA

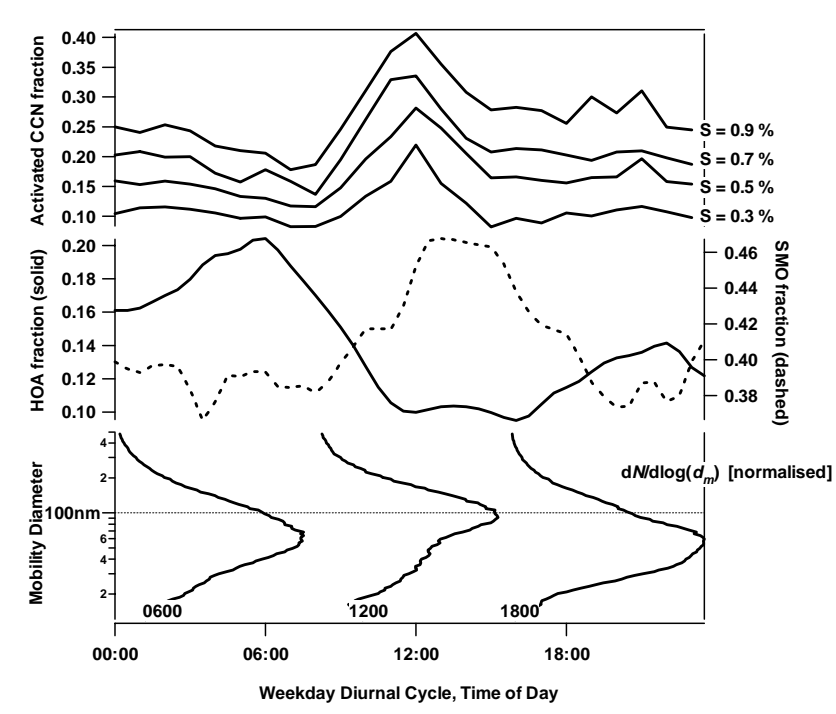

Fig. 3. Weekday diurnal cycles in the $\mathrm{CCN}$ activation, composition and size distribution during the SOAR-1 study. A clear cycle is observed in the $\mathrm{CCN}$ fraction, with the lowest value corresponding to the morning rush hour. The variability in the $\mathrm{CCN}$ cycle corresponds both with variations in the aerosol composition, which exhibits the highest hydrocarbon-like organic aerosol fraction during the rush-hour, and with the size distribution, which grows to larger diameters during the peak in $\mathrm{CCN}$ activation. The fraction of the aerosol mass in the small organic mode does not vary greatly over the diurnal cycle.

fractions of total organics, and the average size distributions from the SMPS are shown in Fig. 3. There is a clear diurnal variability in both the size distribution, which shifts to larger diameters during the afternoon, and the composition, which shows the largest HOA fraction in the morning rush-hour. Both exhibit trends which correlate with the diurnal changes in the $\mathrm{CCN}$ activation, indicating that both influence the $\mathrm{CCN}$ activation properties at Riverside, but the variation in the total SMO fraction (which includes both HOA and OOA mass) over the diurnal cycle is small. Given the observed very repeatable diurnal cycle and the improved signal-to-noise obtained by averaging, the measurements were averaged to a diurnal cycle over the weekday period for input into the model in hour-long steps. Significant changes in emission scenarios of urban areas, and the subsequent impact of urban emissions on the local atmospheric aerosol distribution, may occur between weekends and weekdays, and also between Saturday and Sunday (Harley et al., 2005). Such differences have been shown to exist in the Los Angeles basin (Lough et al., 2006) and given the much reduced statistics, weekends were excluded from the analysis. Averaging to a diurnal cycle is useful to improve counting statistics in the size-resolved composition data as the noise in individual measurement cycles can often introduce unacceptable error into the model predictions. In addition, given the focus of this work to compare the degree of closure between various model assumptions, any small errors induced through diurnal averaging are not critical to the overall conclusions. The various model cases presented in this paper are described below and outlined in Table 1. Figure 4 illustrates the size-resolved compositions used in the models.

\section{Case 1. Complete internal mixture}

Following the methodology of Ervens et al. (2007), in this case the submicron aerosol ensemble is considered as perfectly internally mixed, that is, the aerosol maintains the same (average) chemical composition across the entire particle size range. The time-resolved inorganic (organic) fraction of the aerosol is calculated using the bulk inorganic (organic) fraction measured by the AMS.

\section{Case 2. Complete external mixture}

Using the size-resolved inorganic fraction measured by the AMS, the organic and inorganic components in the model are considered to be externally mixed at all diameters; the organic fraction is treated as entirely non-activating. 


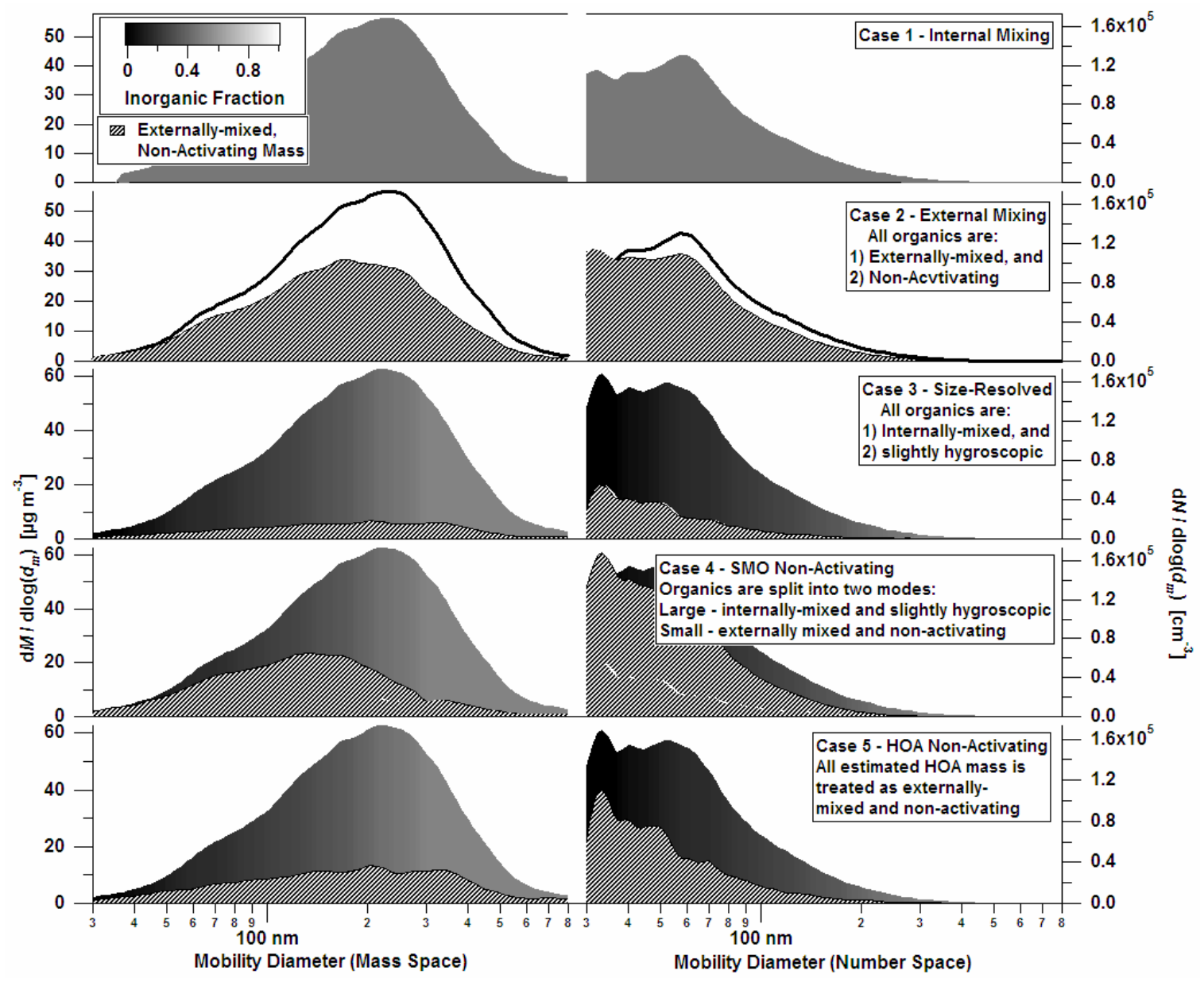

Fig. 4. Size-resolved mass (left) and number (right) distributions for a weekday average from 06:00 to 07:00 h showing the different modal inputs used in the various model cases $\mathrm{C} 1$ to $\mathrm{C} 5$.

Whilst this is clearly an atmospherically-unrealistic case, it is useful to demonstrate the opposite extreme of mixing state from case 1 and the effect it has on the model predictions. It is also relevant to global models, since these typically represent the different aerosol components as externally mixed (Textor et al., 2006).

\section{Case 3. Using size-resolved composition with internal} mixture at each size

The aerosol ensemble maintains the same composition at each particle size class, but the inorganic fraction, and thus the $\kappa$ value, can vary across the size range to account for the dominance of the organic component at the smaller particle diameters. The inorganic fraction at each size is the measured size-resolved inorganic fraction from the AMS. To account for the mass not measured by the AMS, the estimated EC size distribution is considered externally-mixed and non-activating at all diameters.

\section{Case 4. External mixture of small diameter organics}

As for case 3, except that, in addition to the estimated EC, the SMO are considered to be externally-mixed with respect to the background population and treated as nonactivating in the model. This small mode has been observed to be externally-mixed from the large diameter mixed mode and largely hydrophobic in a number of hygroscopicity studies (Svenningsson et al., 1992; McMurry et al., 1996; Weingartner et al., 1997; Swietlicki et al., 1999; Cubison et al., 2006).

Case 5. External mixture eliminating hydrocarbondominated small diameter organics

As for case 4, except that the organics are treated as two different populations. One part, proxied by OOA in the AMS, is treated as weakly-hygroscopic organics in the model with a $\kappa$ value $=0.01$, internally-mixed with the inorganic fraction. The remaining fraction is considered 
externally-mixed and totally non-activating in the model, as determined by measurements of the HOA from the AMS, and single particle information from the ATOFMS.

\section{Results}

Figure 5 shows the scatter plots between the predicted and measured $\mathrm{CCN}$ activated number for the five different supersaturation set points for case $1(\mathrm{C} 1$, complete internal mixing). The particle size distribution is considered as an internal mixture of two species of differing hygroscopicity; no entirely non-activating number fraction (e.g. EC) is considered. In all cases the model prediction is only weakly correlated with the measurements $\left(r^{2} \sim 0.3\right)$, which indicates that, while the diurnal variations in the number concentration and size distribution exhibited in Fig. 3 do influence the $\mathrm{CCN}$ activation, these properties alone cannot explain all the variation in the $\mathrm{CCN}$ measurements. The model also over-predicts the $\mathrm{CCN}$ number concentration by a factor of about three at $S=0.3$ to $0.9 \%$. The much larger overprediction at the lowest $S=0.1 \%$ was also observed by Ervens et al. (2007). This has been attributed to problems with either temperatures (G. Roberts, personal communication) or high flow rates (Lance et al., 2006) in the CCN instrument, which may not allow for enough time for particles to reach sizes large enough to be counted by the OPC at the exit of the CCN chamber. Recently, Rose et al. (2008) noted that deviations between the measured supersaturation and the flow model exceeded $20 \%$ for $S=0.1 \%$, which may also lead to over-prediction in the CCN model. Composition effects such as surface tension and/or other assumptions about soluble organics tend to increase rather than decrease $\mathrm{CCN}$ number, and thus cannot explain the observed discrepancies at $S=0.1 \%$. The results are thus shown for $S=0.1 \%$ for all the model cases, in part to demonstrate the limitations of the instrumentation used in this work, but disregarded in the discussion The over-prediction at $S \geq 0.3 \%$ is expected as many particles smaller than $200 \mathrm{~nm}$ are really organicdominated and thus, even if consisting of water-soluble organic compounds (WSOC), are expected to be only weaklyhygroscopic in nature (Clarke et al., 2007). However, in the model they are assumed to maintain a sizeable, very hygroscopic, inorganic component. It has been previously shown how a small amount of hygroscopic material on a hydrophobic particle can greatly influence its $\mathrm{CCN}$ activation properties (Bilde and Svenningsson, 2004), and thus the assumption that there is inorganic material in all the particles over the entire diameter range falsely increases the $\mathrm{CCN}$ concentration in the model.

The most extreme opposite case from $\mathrm{C} 1$ is the entirely externally-mixed case $\mathrm{C} 2$ as shown in Fig. 6; it is clear that the modeled CCN number concentrations are drastically reduced from $\mathrm{C} 1$, and $\mathrm{C} 2$ tends to under-predict the measurements at the larger supersaturations. The correlation be- tween measurements and model is reduced with respect to $\mathrm{C} 1\left(r^{2} \sim 0.2\right)$, which indicates that the predictive skill of the model is reduced along with the bias. Whilst this demonstrates the large influence of assumed mixing state on CCN prediction in an urban area, the model results cannot be considered valid given that the assumption of complete external mixing is not atmospherically feasible. It is likely that any agreement or correlation with the measurements results from the specific combination of size distributions and mass loadings observed at Riverside. At other locations, model predictions using a similar mixing state assumption have also not been able to reach agreement with measured $\mathrm{CCN}$ numbers (Broekhuizen et al., 2006). We therefore introduce three model cases of increasing complexity using detailed compositional data from the AMS and ATOFMS.

Figure 7 shows the scatter plots between the model and measurements for the $\mathrm{CCN}$ model using internally-mixed, size-resolved composition (Case 3, C3). In order to account for size-resolved mass not measured by the AMS, the estimated EC distribution is considered to be externally-mixed and entirely non-activating in this model.

In the size-resolved case, the smallest particles are almost exclusively organic in nature, as shown in Fig. 3, whereas the larger particles still maintain a large hygroscopic inorganic component. However, unlike the results of Broekhuizen et al. (2006), in which the use of size-resolved composition from an AMS in a CCN model with a hydrophobic organic fraction was shown to achieve closure on an urban dataset, in this work the model still over-predicts the $\mathrm{CCN}$ concentration by around a factor of 2 at the four larger $S$. However, the correlation between the measurements and the model improves from $\mathrm{C} 1$, with $r^{2}$ values $\sim 0.4$, indicating that the variation in size distribution alone is not capturing all the dynamics of the diurnal cycle in the $\mathrm{CCN}$, and that including the size-resolved composition incorporates additional information that improves the predictions. Although the estimated EC is treated as non-activating, it is likely that many of the small diameter organics measured by the AMS are fresh traffic emissions and thus also carbonaceous and truly non-activating in nature. However, in this model they are treated as slightly hygroscopic with a $\kappa$ value of 0.01 , similar to oxidised POA and SOA (Petters and Kreidenweis, 2007). Importantly, the assumption of even small quantities of inorganic mass on the small diameter particles falsely increases the number of $\mathrm{CCN}$, which leads to the observed over-prediction. It thus becomes necessary to use a more complex treatment of the mixing state of the SMO particles.

Figure 8 shows the scatter plots between the CCN model and measurements where all the SMO particles and estimated EC are treated as externally-mixed and entirely nonactivating (Case 4, C4). It was shown in Fig. 3 that the diurnal variation in the SMO was small and indeed, the skill of the model is reduced with the addition of this externally-mixed component which does not follow a clear diurnal pattern similar to the $\mathrm{CCN}$. However, the agreement 


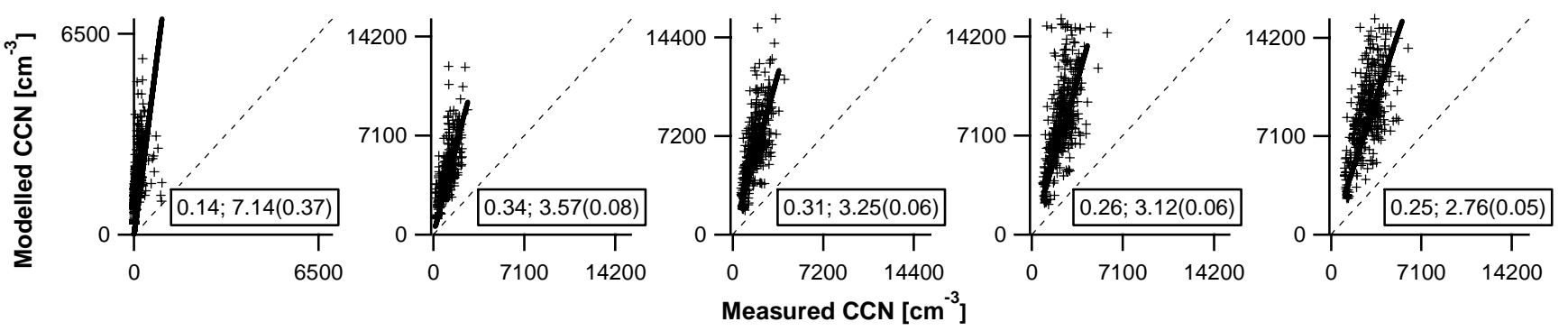

Fig. 5. Comparison of the predicted and measured $\mathrm{CCN}$ for the internal mixing case $\mathrm{C} 1$ at $S=0.1,0.3,0.5,0.7$ and $0.9 \%$; the $r^{2}$ value (left) and slope (with standard deviation in brackets) of a linear regression through the origin (right) are shown on each plot, and the regression line is overlaid on the measurements. Treating the population as completely internally-mixed leads to the model significantly over-predicting the CCN activation at all $S$.
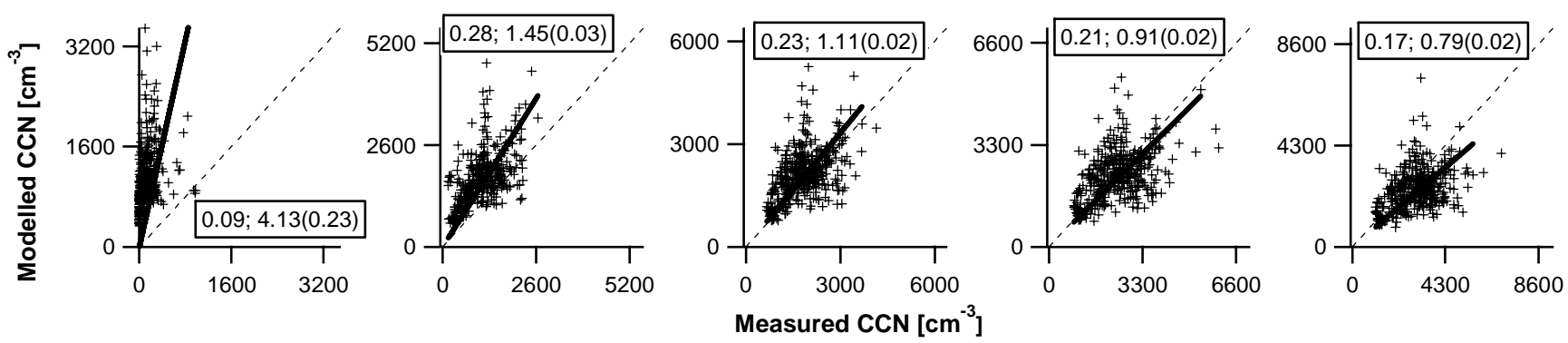

Fig. 6. Comparison of the predicted and measured $\mathrm{CCN}$ using the measured size resolved chemical composition where the distribution is treated as an external mixture of either purely inorganic or non-activating particles (C2), at $S=0.1,0.3,0.5,0.7$ and $0.9 \%$. The $r^{2}$ value (left) and slope (with standard deviation in brackets) of the regression line forced through the origin (right) are shown on each plot, and the regression line is overlaid on the measurements.

is improved significantly with respect to $\mathrm{C} 3$ with overpredictions ranging from zero to $49 \%$.

Earlier work has shown that it is appropriate to treat slightly-hygroscopic organic material as hydrophobic in CCN model studies (Abbatt et al., 2005; Broekhuizen et al., 2006; Ervens et al., 2007; Prenni et al., 2007). Although the SMO mode estimated here is likely to contain both HOA and OOA fractions, the latter of which are likely to be slightly hygroscopic, it appears as though, for the $\mathrm{CCN}$ model, treating the small-mode slightly hygroscopic WSOC material as hydrophobic and thus CCN inactive is also justified in this location.

Recent work has suggested that the HOA fraction of urban aerosol has a significant influence on CCN activation (Quinn et al., 2007). In Fig. 3, the diurnal cycle of the HOA mass fraction was shown to broadly anti-correlate with the $\mathrm{CCN}$ activation. Thus, a case is developed where only those organics deemed hydrocarbon-like in nature in the AMS are considered non-activating in the model; the remainder are left to be treated as a component with a $\kappa$ value of 0.01 in keeping with the previous model cases (Case 5, C5). The quantification of the HOA in $\mathrm{C} 5$ and the assumption that it has a source in local emissions and is carbonaceous in nature are supported by single particle information from the
ATOFMS. When analysing those particles with $d_{v a}<130 \mathrm{~nm}$, where the AMS indicates virtually all the particles observed are in the small organic mode, several different externallymixed particles types are observed (Spencer et al., 2007) with the ATOFMS. The mixing ratio of the different particle classes is found to follow a clear diurnal cycle during the weekday period, with the fraction of those organic particles that are exclusively carbonaceous with no hygroscopic material, classed here as "fresh", reaching a maximum at $06: 00 \mathrm{~h}$ of around 0.35 . The fraction of these particles is observed to decrease to around 0.15 at noon and remain constant through the afternoon. All the remaining particle classes, collectively grouped under the "partially aged" term here, contain oxygenated organic compounds and amines. The fraction of particle mass with $d_{v a}<130 \mathrm{~nm}$ classed as hydrocarbon-like in the AMS, and thus treated as non-activating in the model case of Fig. 9, matches the number fractions from the ATOFMS very closely, varying between 0.15 and 0.35 on the same diurnal cycle. As these carbonaceous particles are likely to be extremely inactive with respect to CCN activation (Dusek et al., 2006b; Ervens et al., 2007), their treatment as totally non-activating in a simple model appears justified. 

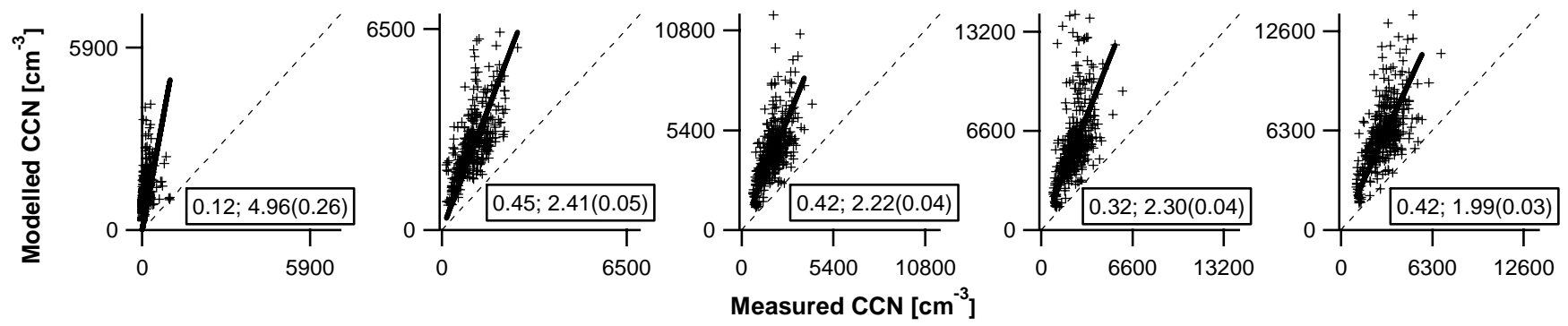

Fig. 7. Comparison of the predicted and measured $\mathrm{CCN}$ using the measured size resolved chemical composition where the small mode organics and estimated elemental carbon as externally-mixed and entirely non-activating (C3), at $S=0.1,0.3,0.5,0.7$ and $0.9 \%$. The $r^{2}$ value (left) and slope (with standard deviation in brackets) of the regression line forced through the origin (right) are shown on each plot, and the regression line is overlaid on the measurements. Although the smaller particles are now treated as organic-dominated, the model still over-predicts the $\mathrm{CCN}$ activation.
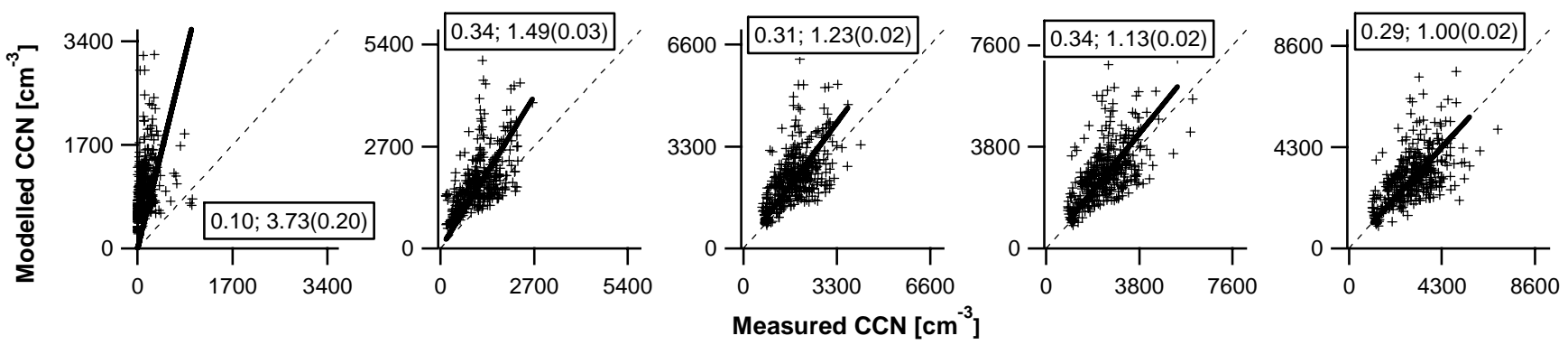

Fig. 8. Comparison of the predicted and measured $\mathrm{CCN}$ using the measured size resolved chemical composition where the small mode organics and estimated elemental carbon are treated as externally-mixed and entirely non-activating (C4), at $S=0.1,0.3,0.5,0.7$ and $0.9 \%$. The $r^{2}$ value (left) and slope (with standard deviation in brackets) of the regression line forced through the origin (right) are shown on each plot, and the regression line is overlaid on the measurements. By assuming all the small mode organics are completely hydrophobic, the model now reaches reasonable agreement with the measurements on $\mathrm{CCN}$ activation.

Figure 9 shows the scatter plot between the model and the measurements for $\mathrm{C} 5$, where the model over-predicts by between 68 and $100 \%$. This is a greater over-prediction than observed for $\mathrm{C} 4$, suggesting that developing a parameterisation for the mixing state and hygroscopicity of not only the HOA fraction, but also the SMO, is important for modeling $\mathrm{CCN}$ activation in this location. However, as a result of integrating a non-activating component with a diurnal cycle broadly anticorrelated with that of the $\mathrm{CCN}$ fraction, the skill of the model is improved from $\mathrm{C} 4$, with $r^{2}$ values around 0.4 . Nonetheless, the over-prediction in C5 suggests that the oxygenated organics observed in the AMS and ATOFMS for the SMO are also largely CCN inactive in this dataset. Figure 10 shows the weekday diurnal cycles in both the aerosol number from the condensation nucleus $(\mathrm{CN})$ counter and activated $\mathrm{CCN}$ at $S=0.5 \%$, together with the diurnal cycles in $\mathrm{CCN}$ at $S=0.5 \%$ predicted by the five different model cases. The variation in the size distribution allows $\mathrm{C} 1$, with limited compositional influence, to capture the general diurnal profile of the activated CCN. By declaring as non-activating a component broadly anti-correlated with CCN activation, $\mathrm{C} 5$ most accurately captures the diurnal cycle in the $\mathrm{CCN}$, while $\mathrm{C} 2$ and
$\mathrm{C} 4$ are closest to reaching agreement with the measurements. However, all of the models over-predict most strongly during the $\mathrm{CN}$ peak in the morning rush-hour period, where only a subset of the emissions particles are activated (this is clearly shown by the activated fraction traces in Fig. 3). Further suppression of the $\mathrm{CCN}$ activation properties of the fresh traffic emissions particles that dominate the number concentration during this period would be required in the model in order to reach agreement with the measurements. It is possible that small, fractal, emissions particles which are classified by the mobility analysis as larger than their true size (DeCarlo et al., 2004) are then activated in the CCN model. In addition, recent work has shown that kinetic limitations on cloud droplet formation, which are not considered in this study, may significantly slow the activation of particles in polluted urban areas (Ruehl et al., 2008). The temporal pattern of CCN number concentration observed at Riverside, with the largest deviation from the modeled values observed during the peak of fresh urban emissions, can be at least qualitatively explained through this effect. 


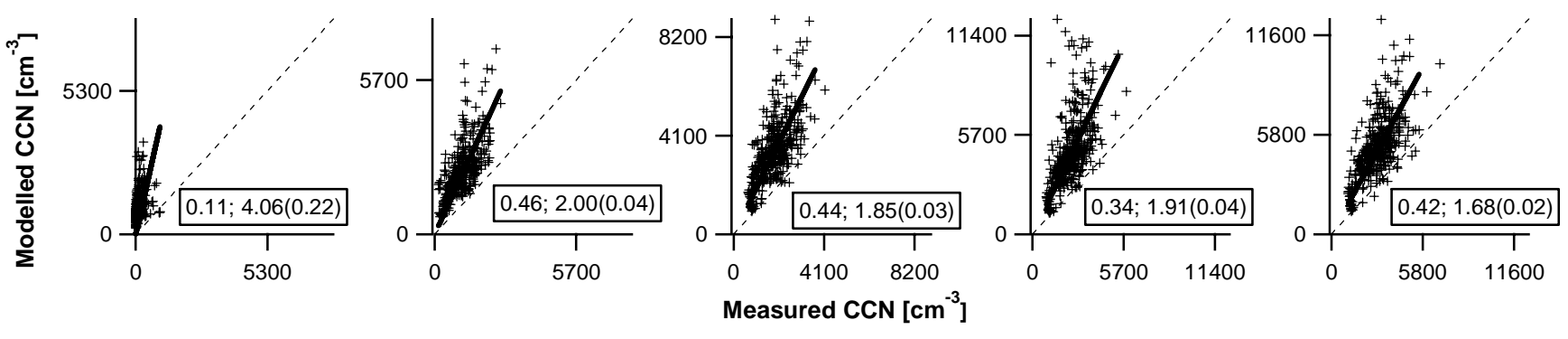

Fig. 9. Comparison of the predicted and measured $\mathrm{CCN}$ using the measured size resolved chemical composition where the hydrocarbon-like organic aerosol (HOA) and estimated elemental carbon (EC) are treated as externally-mixed and entirely non-activating, at $S=0.1,0.3,0.5$, 0.7 and $0.9 \%$ (C5). The $\mathrm{r}^{2}$ value (left) and slope (with standard deviation in brackets) of the regression line forced through the origin (right) are shown on each plot, and the regression line is overlaid on the measurements.

\section{Discussion}

Although Fig. 8 shows a good degree of closure between the model and the measurements when the SMO and EC particles are treated as non-activating (C4), the model is dependent on the basic properties of the weakly-hygroscopic OOA which is internally mixed with the inorganics in the large mixed mode. Changing the $\kappa$ value of the weaklyhygroscopic OOA from 0.01 (c.f. oxidised POA (Petters et al., 2006), Fig. 8) to 0.13 (c.f. chamber studies of SOA (AsaAwuku et al., 2007) for the organic fraction increases the slope of the regression lines by between 14 and 30\% over the different supersaturation values, as shown for $S=0.5 \%$ in Fig. 11. Further increasing the large-mode organic $\kappa$ value to that of ammonium sulphate decreases the skill of the model and further increases the degree of over-prediction in the model. It is noted that decreasing the $\kappa$ of the organics to values approaching zero does not significantly decrease the degree of over-prediction at $S=0.5 \%$ in the model.

Unlike in our study, Broekhuizen et al. (2006) achieved $\mathrm{CCN}$ closure on an urban dataset using a model case similar to $\mathrm{C} 3$, but treating the organics as hydrophobic in nature. However, Fig. 12 shows that at Riverside, the size resolved model case C 3 is largely insensitive to the organic hygroscopicity, where applying a $\kappa$ value as low as $\sim 0.0004$ does not greatly decrease the level of over-prediction observed in the model. In this methodology it is clear that the incorrect assumption of internal mixing causes small quantities of inorganic mass on the smaller particles to dominate the $\mathrm{CCN}$ activation properties.

In summary, although the model is somewhat sensitive to the assumptions used about the inherent properties of the weakly-hygroscopic organics in the large mixed mode, it is clear that well-correlated closure can only be achieved using additional treatment of the mixing state beyond the use of a size-resolved organic fraction. The large diameter mixed mode is ubiquitously observed throughout the Northern Hemisphere and many field studies demonstrating this are summarized in Canagaratna et al. (2007). The organic

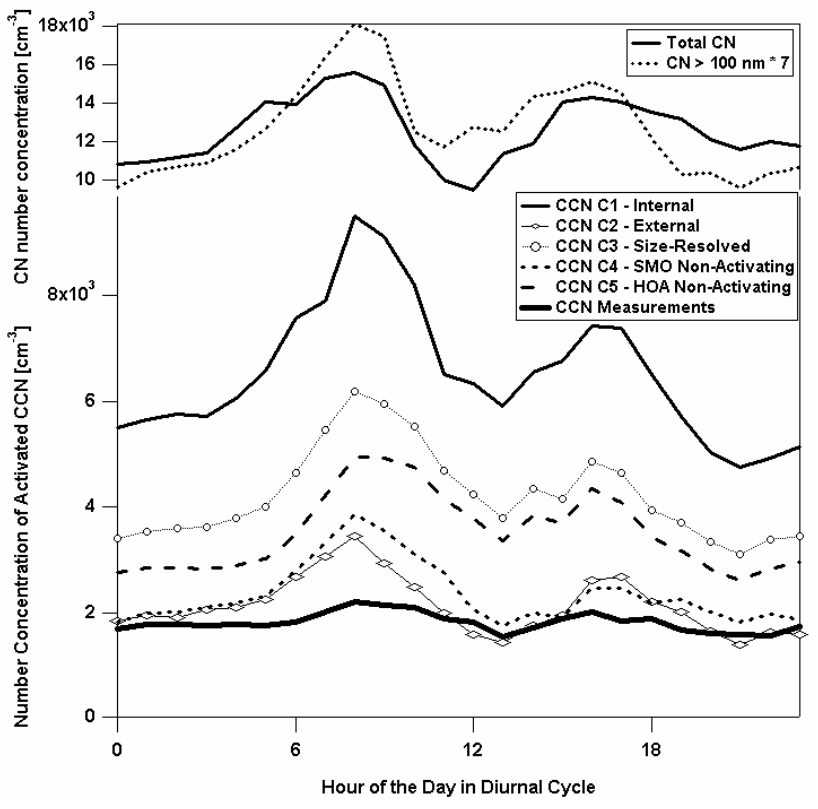

Fig. 10. Summary of the weekday diurnal cycles in CCN activation predicted by the five cases and measured by the $\mathrm{CCN}$ counter at $S=0.5 \%$, together with the weekday diurnal cycle observed in the total and $>100 \mathrm{~nm}$ aerosol condensation nucleus $(\mathrm{CN})$ measurements. The standard deviation on the diurnal averages arising from daily variability in the number concentration ranges from $20-40 \%$ of the average value for both $\mathrm{CN}$ and $\mathrm{CCN}$ measurements. All the cases over-predict the measured $\mathrm{CCN}$ during the morning rush-hour period, where the top dashed line shows large $\mathrm{CN}$ exist but do not efficiently activate as per the measurements.

component of this mode was shown by Ervens et al. (2007) to be largely hydrophobic with respect to $\mathrm{CCN}$ activation at a marine background location. Given that the best agreement is reached for $\mathrm{C} 4$ when the organic $\kappa$ value is small, this finding is also supported here in an urban location, highlighting common activation properties of the ubiquitous large mode over different geographical settings. 

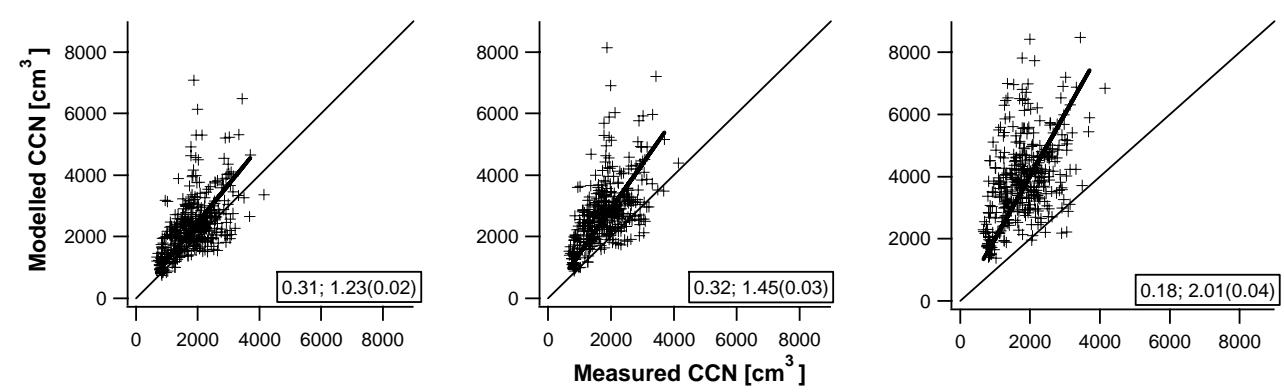

Fig. 11. Comparison of the predicted and measured $\mathrm{CCN}$ using $\mathrm{CCN}$ model case 4 (of Fig. 8) at $S=0.5 \%$; the reference case from Fig. 8 is shown on the left. Centre and right use the same model where the organics have $\kappa$ values of 0.13 and 0.5 (cf. $\kappa=0.01$ in the reference case). The $r^{2}$ value (left) and slope (with standard deviation in brackets) of the regression line forced through the origin (right) are shown on each plot, and the regression line is overlaid on the measurements.
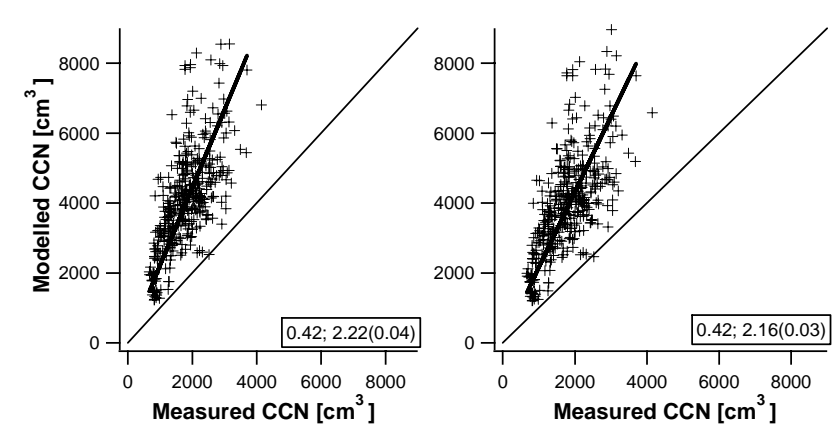

Fig. 12. Comparison of the predicted and measured CCN using CCN model case 3 (of Fig. 7) at $S=0.5 \%$; the reference case from Fig. 7 is shown on the left. The plot on the right uses the same model where the organics have a $\kappa$ value approaching zero. The $\mathrm{r}^{2}$ value (left) and slope (with standard deviation in brackets) of the regression line forced through the origin (right) are shown on each plot, and the regression line is overlaid on the measurements. Further decreasing the hygroscopicity of the organics in the model does not significantly decrease the predicted CCN concentration.

Given that some previous studies have been able to show closure without explicit treatment of externally-mixed modes, we consider to what extent it is necessary to consider externally-mixed SMO aerosol in CCN modeling over the global atmosphere. It is clear that the background location studies would not need treatment of a fresh emissions component that is absent in such locations. Indeed, $\mathrm{C} 1$, using the assumption of internal mixing, was successfully used to achieve closure on the measurements from the background marine site at Chebogue Point, Nova Scotia (Ervens et al., 2007), but in that case the aged ( $\geq 2$ day) pollution and remote continental aerosol did appear internallymixed and soluble in nature and thus the inorganic material was indeed observed to be spread across the whole particle diameter range, indicating that the internal mixing assumption is appropriate for this type of aged air mass. Many air masses worldwide are likely to exhibit characteristics some- where between the two opposite cases observed at Chebogue Point and Riverside. It has been shown that urban emissions are transformed by atmospheric processes such as coagulation and condensation as they are diluted during advection downwind from the emissions area (Riemer et al., 2004; $\mathrm{Cu}-$ bison et al., 2006; de Gouw et al., 2005; Volkamer et al., 2006; Zhang et al., 2007). The timescales for the primary hydrophobic mass of these aerosols to be no longer a significant component of the particle mass (mainly due to dilution with regional air and condensation of secondary species) were found to be between 1 to 2 days. After this time period, the less-hygroscopic mode is no longer visible in hygroscopicity measurements (Cubison et al., 2006) and it is thus unlikely that explicit treatment of the non-activating number fraction would be required beyond this timescale to achieve $\mathrm{CCN}$ closure. It is clear that, with the expansion of urban population and megacities worldwide, that there are significant areas of the atmosphere, both over these metropolitan areas and immediately downwind, where such calculations could benefit from inclusion of a simple treatment of the nonactivating particles such as that presented here.

\section{Cloud droplet model}

\subsection{Model parameters}

While the $\mathrm{CCN}$ calculations are performed for equilibrium conditions using the Köhler equation, i.e. for a prescribed supersaturation, in a parcel model the supersaturation in a cloud is represented by (i) a dynamic term that represents the source of supersaturation and (ii) the condensation term that depends on the size and composition of the particles, and the supply of water vapour. Thus it is not prudent to assume that conclusions drawn about particle activation properties from $\mathrm{CCN}$ counter studies can be used to infer the same for cloud droplet formation under real atmospheric conditions. The cloud droplet modelling study of Ervens et al. (2005) showed that the greatest impact of chemical composition on 

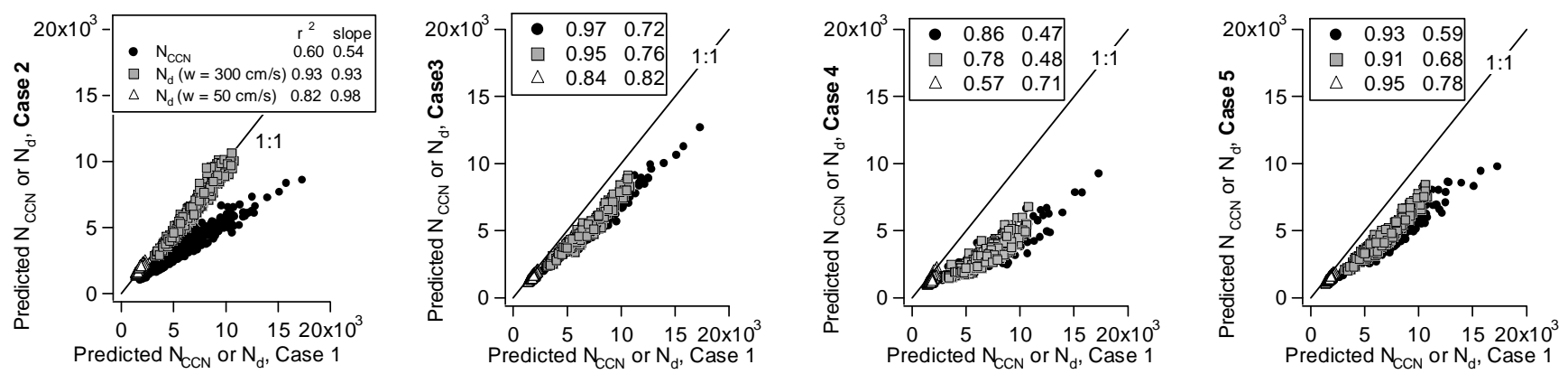

Fig. 13. Predicted CCN numbers and cloud droplet numbers (for two different updraft velocities) using the different model cases. The numbers in the upper right corner are the $\mathrm{r}^{2}$ and slopes of the regression lines.

cloud droplet concentrations occurs at low supersaturation (i.e. low updraft and/or high aerosol concentrations), whereas at higher updrafts/lower aerosol concentrations, the composition effects are reduced. Further to their approach, we expand the $\mathrm{CCN}$ model results to consider the impact of the different composition and mixing state cases (C1-C5) on cloud droplet number concentrations.

Assuming adiabatic conditions for an ascending air parcel until a maximum liquid water content $\left(0.3 \mathrm{~g} \mathrm{~m}^{-3}\right.$, typical for stratocumulus clouds) is reached, we compare the cloud properties that are predicted for model cases C2, C3, C4 and $\mathrm{C} 5$ to those predicted for the internally-mixed case $\mathrm{C} 1$. We somewhat arbitrarily define the total drop number concentration $N_{d}$ as the population of all particles (drops) $>2 \mu \mathrm{m}$ in diameter, unlike in CCN studies where we consider the number of activated particles according to Köhler theory.

\subsection{Predicted cloud droplet number concentrations $N_{d}$}

In Fig. 13, we compare the $\mathrm{CCN}$ concentrations predicted for the internally-mixed cloud model case $\mathrm{C} 1$ to those predicted for $\mathrm{C} 2, \mathrm{C} 3, \mathrm{C} 4$ and $\mathrm{C} 5$, for $S=0.5 \%$. The slopes were observed to be mostly independent of the value of $\mathrm{S}$ and thus results are only shown for one supersaturation. The only difference in this trend is represented by $\mathrm{C} 4$, as a significant fraction of particles are externally-mixed from the large mode and thus the number of activated particles increases more in $\mathrm{C} 1$ than $\mathrm{C} 4$ with increasing supersaturation, as in $\mathrm{C} 4$ the critical diameter moves into the region where many SMO particles are considered non-activating.

Superimposed on the same plot are predictions of $N_{d}$ that result from two different updraft velocities $\left(w=50 \mathrm{~cm} \mathrm{~s}^{-1}\right.$ and $w=300 \mathrm{~cm} \mathrm{~s}^{-1}$ ). It should be noted that the maximum supersaturations reached in the modelled air parcels differ from the single supersaturation value used in the comparisons detailed above $\left(S_{3} \sim 0.5 \%\right)$ as they depend on $w$, aerosol composition and size distributions: At $w=50 \mathrm{~cm} \mathrm{~s}^{-1}$, the calculated maximum supersaturations are $\sim 0.1-0.4 \%$ whereas those at the higher updraft $\left(w=300 \mathrm{~cm} \mathrm{~s}^{-1}\right)$ are in the range of $0.4-1 \%$. Both the comparisons for $\mathrm{C} 3$ and $\mathrm{C} 5$ vs. $N_{\mathrm{CCN}}(\mathrm{C} 1)$ exhibit

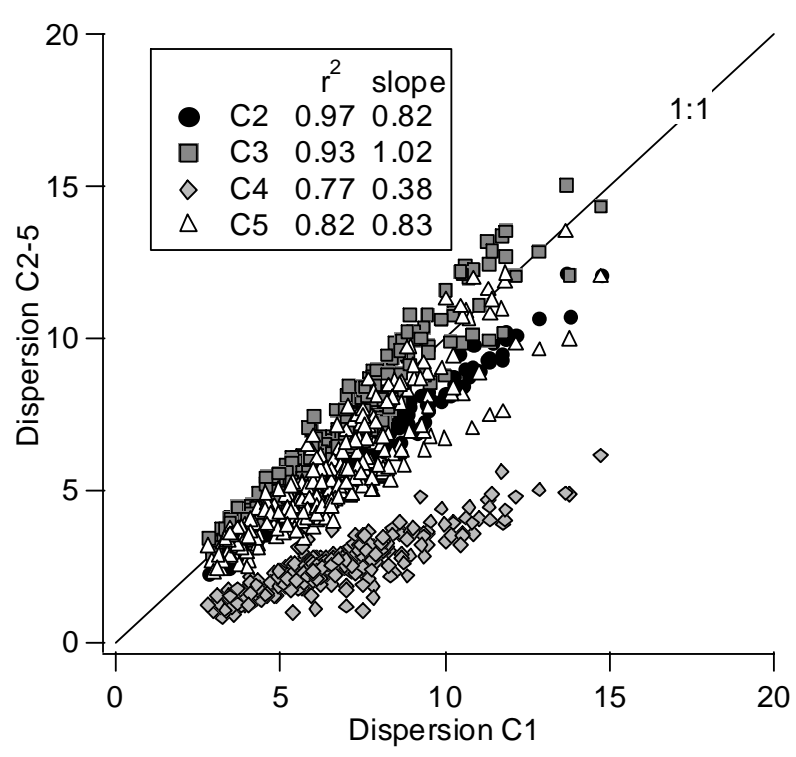

Fig. 14. Comparison of dispersion of cloud droplet size distribution at liquid water content $0.3 \mathrm{~g} \mathrm{~m}^{-3}\left(\mathrm{w}=50 \mathrm{~cm} \mathrm{~s}^{-1}\right)$ for model cases 2 , 3,4 , and 5 vs. $\mathrm{C} 1$ (see text).

very similar slopes. C3 and C5 only differ by the properties of the small particles $(<\sim 200 \mathrm{~nm}$ diameter) which are assumed to be an externally-mixed non-activating mode in C5 while they are hygroscopic and internally-mixed in case C3. Such small particles are mainly just above the typical critical activation diameter and, in the unlimited water supply in the Köhler CCN model, will activate. However, in the cloud model, under competition for water vapour, they may not grow to the $2 \mu \mathrm{m}$ cut-point before the maximum liquid water content is reached.

In all cases $N_{d}$ is much smaller than $N_{\mathrm{CCN}}$ for low updraft velocity because (i) less particles are activated and grow to drop sizes in an ascending cloud parcel due to limited growth time and limited supply of water vapour due to competition for available vapour and (ii) we apply different definitions for $N_{\mathrm{CCN}}$ (= particles that exceed their critical size according to 


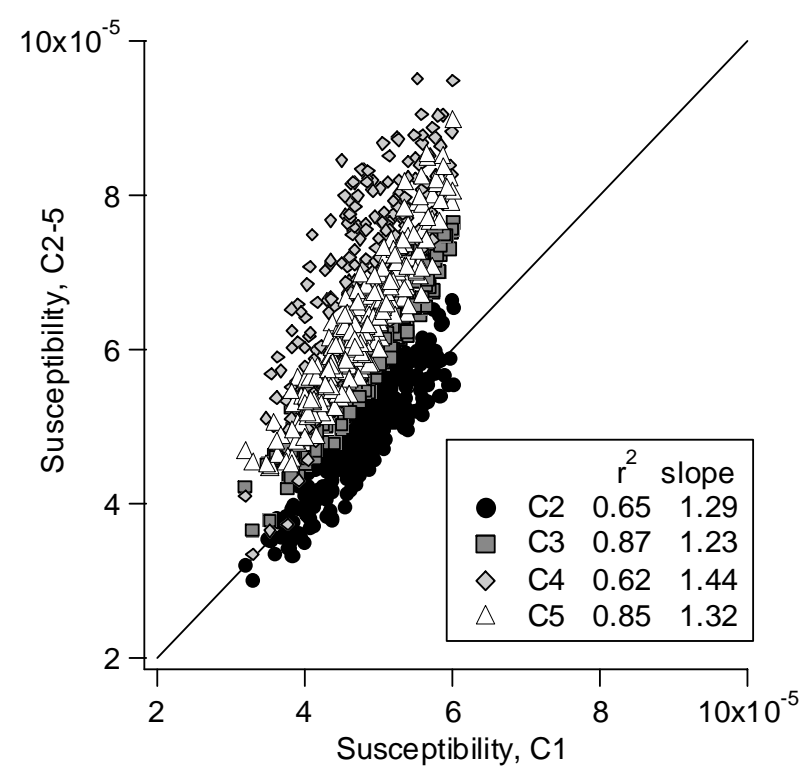

Fig. 15. Comparison of cloud susceptibility (Eq.-2) at liquid water content $0.3 \mathrm{~g} \mathrm{~m}^{-3}\left(\mathrm{w}=50 \mathrm{~cm} \mathrm{~s}^{-1}\right)$ for model cases $2,3,4$, and $5 \mathrm{vs}$. C1 (see text).

Köhler theory) and $N_{d}$ (particles that exceed the diameter of $2 \mu \mathrm{m})$, respectively.

In general, all regression lines for $N_{d}$ in Fig. 13 show the same trend as predicted for $N_{\mathrm{CCN}}$ but have higher slopes. This reiterates the point that composition effects on $\mathrm{CCN}$ are not the same as composition effects on $N_{d}$ (Ervens et al., 2005), and that differences are reduced when considering effects on $N_{d}$. The differences in the slope for $w=50 \mathrm{~cm} \mathrm{~s}^{-1}$ and $w=300 \mathrm{~cm} \mathrm{~s}^{-1}$ are different from the results of Ervens et al. (2005) where it was found that at higher updraft velocities composition effects are reduced (and, thus, should exhibit slopes closer to the 1:1 line). In our case the opposite is observed. However, the latter study considered only a pure internally mixed aerosol (c.f. C1 in this study) and no change in soluble fraction and/or mixing state with size. In the current data set, smaller particles are less hygroscopic (or even completely non-activating) and with increasing updraft, for these cases, fewer particles can be activated compared to the more hygroscopic aerosol population assumed in $\mathrm{C} 1$.

\section{Dispersion of cloud droplet size distributions}

At constant liquid water content (LWC), an increase in aerosol number leads to an increase in cloud drop number, and decrease in droplet size at constant LWC (Twomey, 1977). Twomey's theoretical calculations assume that the shape of the drop size distribution is constant. However, observations in polluted areas have shown that an increase in drop number concentration associated with an increase in anthropogenic emissions usually leads to an increase in the relative dispersion, $D$, defined as the ratio of the standard deviation to the mean radius, of the drop size distribution at the small-drop end (Liu and Daum, 2002). This effect results from the fact that condensational growth tends to narrow the size distribution. In polluted conditions, the increased competition for water vapour results in less growth per droplet, and therefore less spectral narrowing due to the condensation process.

In Fig. 14 we compare $D$ of the resulting cloud droplet size distributions for the five different cases at $w=50 \mathrm{~cm} \mathrm{~s}^{-1}$. We only show results for $w=50 \mathrm{~cm}^{-1}$, where the supersaturation is small and the relative importance of the condensation (composition) term is higher in the case of an internally mixed aerosol population (Ervens et al., 2005). Again, we compare the results of model cases $\mathrm{C} 2$ to $\mathrm{C} 5$ to those of the pure internal mixture $(\mathrm{C} 1)$. Figure 14 shows similar $D$ for $\mathrm{C} 1, \mathrm{C} 3$ and $\mathrm{C} 5$ even though $\mathrm{C} 1$ exhibits larger drop number concentrations, which is a function of the mixing state and composition assumptions applied in the different cases. For the large particles, a small hygroscopic fraction is sufficient to initiate efficient growth and, thus, the largest drop diameters do not differ much for cases C1, C3 and C5. However, for smaller size particles, differences in hygroscopicity change the growth rates of individual particles, and, thus, the shape (breadth) of the resulting drop size distribution. This effect is even more pronounced since the most significant differences in hygroscopicity are in the size range of $\sim 100 \mathrm{~nm}$ which is about the size of the smallest activated particles. Therefore the case where the SMO particles are considered externally-mixed and totally non-activating (C4) leads to a narrower size distribution because fewer drops are activated (many of the particles are not hygroscopic) and there is more condensation growth per drop. The presence of a large number of externally mixed hydrophobic particles does not influence cloud properties and indeed this case resembles a somewhat clean case with smaller $\mathrm{CCN}$ and drop number concentrations.

\subsection{Cloud susceptibility $\mathrm{S}_{s c}$}

Cloud susceptibility $S_{s c}$ is defined as the change in cloud albedo $A$ for a change in drop number concentration $N_{d}$ under conditions of constant cloud liquid water path (LWP), and fixed drop size distribution shape (Twomey, 1991):

$S_{s c}=\left|\frac{\partial \ln A}{\partial \ln N_{d}}\right|_{\text {LWP, shape }}=\frac{A(1-A)}{3 N_{d}}$

where albedo is calculated based on the expression by Bohren (1987) for a plane-parallel cloud:

$\mathrm{A}=\frac{(1-\mathrm{g}) \tau}{2+(1-\mathrm{g}) \tau}$

with $g=$ asymmetry factor for cloud droplets $(\approx 0.84)$ and $\tau=$ cloud optical depth. The liquid water path is $\sim 80 \mathrm{~g} / \mathrm{m}^{2}$ for the cloud-top liquid water content of $0.3 \mathrm{~g} \mathrm{~m}^{-3}$ and 
the assumed cloud base temperature $(288 \mathrm{~K})$ and pressure (919 mbar).

We have used the effects of aerosol on cloud albedo, as represented by Eq. (3) as a measure of the aerosol indirect effect and calculated $S_{s c}$, shown in Fig. 15 (for an updraft velocity of $\mathrm{w}=50 \mathrm{~cm} \mathrm{~s}^{-1}$ ) for $\mathrm{C} 1$ to $\mathrm{C} 5$. At higher aerosol concentrations the response of cloud optical properties to the increase in aerosol number is smaller, i.e., the cloud susceptibility is lower. This is the case for C1, C3 and C5. In the external mixture of $\mathrm{C} 4$, the drop number concentration is lowest and thus $\mathrm{C} 4$ exhibits the highest values of $S_{s c}$. The tendency to narrower size distributions in $\mathrm{C} 4$ decreases this effect to a small extent (Feingold et al., 1997), but the influence due to $N_{d}$ is strongest.

This finding reinforces the importance of the mixing state of particles, as mediated by $N_{d}$, on cloud optical properties (e.g. Broekhuizen et al., 2006; Medina et al., 2007). The small influence on $N_{d}$ from changes in the hygroscopicity of internally-mixed particles containing very hygroscopic material translates to a small influence on the optical properties.

\section{Conclusions}

A number of different model cases are presented for attempting $\mathrm{CCN}$ closure between measurements of the physical and chemical properties of urban aerosol at Riverside, CA, USA, and their CCN activation. A CCN model is used to consider both internally- and externally-mixed aerosol populations, and it is shown that treatment of externally-mixed components is necessary to approach closure in a highly polluted urban area in the presence of freshly emitted particles. However, the over-prediction observed in all the models during the morning rush-hour indicates that there are additional effects influencing the $\mathrm{CCN}$ activation, such as further complexity in the mixing state, over-sizing of fractal particles by the SMPS, kinetic limitations to CCN activation or possible bias in the measurements.

Size-resolved chemical composition is required to differentiate between the hygroscopic organic and inorganic aerosol components. In order to achieve good closure with significant correlation in this urban location using atmospherically-relevant assumptions for the internallymixed hygroscopic organics in the model, and taking into account mass not measured by the AMS, it is necessary to treat non-activating urban emissions particles, here observed as EC and SMO, as externally-mixed with respect to the remainder of the aerosol population. In addition, it is found that the organic component of the accumulation mode exhibits CCN activation properties similar to those found in a coastal location (Ervens et al., 2007), behaving as effectively hydrophobic mass in the $\mathrm{CCN}$ model. Closure studies using the same model at further locations would help determine if the observed hydrophobicity of the SMO in Ervens et al. (2007) and this work is applicable for the hygroscopic large mixed mode which has been observed ubiquitously in Northern Hemisphere locations (Alfarra et al., 2004; Canagaratna et al., 2007).

In addition, we explored the extent to which such differences in composition and mixing state translate into differences in predicted cloud microphysical and optical properties. The cloud model considers the role of supersaturation sources and sinks in an adiabatic air parcel that more closely reflects conditions in natural clouds than does the static supersaturation in a $\mathrm{CCN}$ counter where all the particles are given enough residence time to reach equilibrium conditions. As shown in previous model studies, in an adiabatically rising air parcel the maximum supersaturation is determined by both the updraft, and the size distribution/composition of the particles. The negative feedback between the vapour source and sink terms results in a reduced influence of composition on drop activation than for assumed equilibrium conditions, consistent with previous results of Ervens et al. (2005). The size-resolved hygroscopicity of an internally mixed aerosol population influences both cloud drop number concentration and the shape of the cloud drop size distribution, and we have shown that these effects may enhance or counter one another in the calculation of the cloud susceptibility. However, significant decrease in the cloud drop number concentration as caused by a large fraction of externally-mixed non-activating particles overwhelms shape effects on cloud albedo and susceptibility. The only distinct composition differences occur if external vs. internal mixtures are compared, since the potential number of activated particles changes significantly. Thus, the mixing state of particles with sizes larger than critical diameters, and significant differences in the hygroscopic properties of separate modes have to be known in order to give a reliable estimate of aerosol influences on cloud microphysical and optical properties.

Acknowledgements. The authors would like to thank J. Ogren, B. Andrews and P. Sheridan of NOAA ESRL for the loan and instruction in use of the DMT CCN counter for the SOAR-1 campaign, Thanos Nenes of Georgia Tech. for use of the DMT $\mathrm{CCN}$ counter simulation model for calculation of the instrument operational supersaturation values and James Schauer and David Snyder for providing EC data. The support of the entire SOAR team, in particular Paul Ziemann, has been much appreciated. GF and BE acknowledge support from NOAA's Climate Goal. This work was funded by US EPA STAR grants RD83216101-0 and R831080 and by NSF grant ATM-0449815. IU acknowledges a NASA Earth Science Fellowship (NNG05GQ50H). This paper has not been reviewed by either funding agency and no official endorsement should be inferred.

Edited by: K. Hämeri 


\section{References}

Abbatt, J. P. D., Broekhuizen, K., and Kumal, P. P.: Cloud condensation nucleus activity of internally mixed ammonium sulfate/organic acid aerosol particles, Atmos. Environ., 39, 47674778, 2005.

Albrecht, B. A.: Aerosols, clouds and microphysics., Science, 245, 1227-1230, 1989.

Alfarra, M. R., Coe, H., Allan, J. D., Bower, K. N., Boudries, H., Canagaratna, M. R., Jimenez, J. L., Jayne, J. T., Garforth, A. A., Li, S.-M., and Worsnop, D. R.: Characterization of urban and rural organic particulate in the Lower Fraser Valley using two Aerodyne Aerosol Mass Spectrometers., Atmos. Environ., 38, 5745-5758, 2004.

Allan, J. D., Delia, A. E., Coe, H., Bower, K. N., Alfarra, M. R., Jimenez, J. L., Middlebrook, A. M., Jayne, J. T., and Worsnop, D. R.: A generalised method for the extraction of chemically resolved mass spectra from Aerodyne aerosol mass spectrometer data., J. Aerosol Sci., 35, 909-922, 2004.

Anttila, T. and Kerminen, V. M.: On the contribution of Aitken mode particles to cloud droplet populations at continental background areas - a parametric sensitivity study, Atmos. Chem. Phys., 7, 4625-4637, 2007,

http://www.atmos-chem-phys.net/7/4625/2007/.

Asa-Awuku, A., Nenes, A., Gao, S., Flagan, R. C., and Seinfeld, J. H.: Alkene ozonolysis SOA: inferences of composition and droplet growth kinetics from Köhler theory analysis, Atmos. Chem. Phys. Discuss., 7, 8983-9011, 2007,

http://www.atmos-chem-phys-discuss.net/7/8983/2007/.

Bein, K. J., Zhao, Y. J., Wexler, A. S., and Johnston, M. V.: Speciation of size-resolved individual ultrafine particles in Pittsburgh, Pennsylvania, J. Geophys. Res., 110, D07S05, doi:10.1029/2004JD004708, 2005.

Bilde, M. and Svenningsson, B.: CCN activation of slightly soluble organics: the importance of small amounts of inorganic salt and particle phase, Tellus B, 56, 128-134, 2004.

Bohren, C.: Mulitple light scattering of light and some of its observable consequences, Am. J. Phys., 55, 524-533, 1987.

Broekhuizen, K., Chang, R. Y. W., Leaitch, W. R., Li, S. M., and Abbatt, J. P. D.: Closure between measured and modeled cloud condensation nuclei $(\mathrm{CCN})$ using size-resolved aerosol compositions in downtown Toronto, Atmos. Chem. Phys., 6, 2513-2524, 2006 ,

http://www.atmos-chem-phys.net/6/2513/2006/.

Canagaratna, M. R., Jayne, J. T., Jimenez, J. L., Allan, J. D., Alfarra, M. R., Zhang, Q., Onasch, T. B., Drewnick, F., Coe, H., Middlebrook, A., Delia, A., Williams, L. R., Trimborn, A. M., Northway, M. J., DeCarlo, P. F., Kolb, C. E., Davidovits, P., and Worsnop, D. R.: Chemical and microphysical characterization of ambient aerosols with the Aerodyne aerosol mass spectrometer, Mass Spectrom. Rev., 26, 185-222, 2007.

Chuang, P. Y., Collins, D. R., Pawlowska, H., Snider, J. R., Jonsson, H. H., Brenguier, J. L., Flagan, R. C., and Seinfeld, J. H.: CCN measurements during ACE-2 and their relationship to cloud microphysical properties, Tellus B, 52, 843-867, 2000.

Clarke, A., McNaughton, C., Kasputin, V. N., Shinozuka, Y., Howell, S., Dibb, J., Zhou, J., Anderson, B., Brekhovskikh, V., Turner, H., and Pinkerton, M.: Biomass burning and pollution aerosol over North America: Organic components and their influence on spectral optical properties and humidification response, J. Geophys. Res., 112, D12S18, doi:10.1029/2006JD007777, 2007.

Cubison, M. J., Alfarra, M. R., Allan, J., Bower, K. N., Coe, H., McFiggans, G. B., Whitehead, J. D., Williams, P. I., Zhang, Q., Jimenez, J. L., Hopkins, J., and Lee, J.: The characterisation of pollution aerosol in a changing photochemical environment, Atmos. Chem. Phys., 6, 5573-5588, 2006,

http://www.atmos-chem-phys.net/6/5573/2006/.

de Gouw, J. A., Middlebrook, A. M., Warneke, C., Goldan, P. D., Kuster, W. C., Roberts, J. M., Fehsenfeld, F. C., Worsnop, D. R., Canagaratna, M. R., Pszenny, A. A. P., Keene, W. C., Marchewka, M., Bertman, S. B., and Bates, T. S.: Budget of organic carbon in a polluted atmosphere: Results from the New England Air Quality Study in 2002, J. Geophys. Res., 110, D16305, doi:10.1029/2004JD005623, 2005.

DeCarlo, P. F., Slowik, J. G., Worsnop, D. R., Davidovits, P., and Jimenez, J. L.: Particle morphology and density characterization by combined mobility and aerodynamic diameter measurements, Part 1: Theory, Aerosol Sci. Technol., 38, 1185-1205, 2004.

DeCarlo, P. F., Kimmel, J. R., Trimborn, A., Jayne, J. T., Aiken, A. C., Gonin, M., Fuhrer, K., Horvath, T., Docherty, K., Worsnop, D. R., and Jimenez, J. L.: A Field-Deployable High-Resolution Time-of-Flight Aerosol Mass Spectrometer., Anal. Chem., 78, 8281-8289, 2006.

Dinar, E., Taraniuk, I., Graber, E. R., Katsman, S., Moise, T., Anttila, T., Mentel, T. F., and Rudich, Y.: Cloud Condensation Nuclei properties of model and atmospheric HULIS, Atmos. Chem. Phys., 6, 2465-2481, 2006,

http://www.atmos-chem-phys.net/6/2465/2006/.

Docherty, K. S., Stone, E. A., Ulbrich, I. M., DeCarlo, P. F., Snyder, D. C., Schauer, J. J., Peltier, R. E., Weber, R. J., Murphy, S. M., Seinfeld, J. H., Eatough, D. J., and Jimenez, J. L.: Apportionment of Primary and Secondary Organic Aerosols in Southern California during the 2005 Study of Organic Aerosols in Riverside (SOAR), Environ. Sci. Technol., ASAP paper, doi:10.1021/es8008166, 2008.

Drewnick, F., Hings, S. S., DeCarlo, P., Jayne, J. T., Gonin, M., Fuhrer, K., Weimer, S., Jimenez, J. L., Demerjian, K. L., Borrmann, S., and Worsnop, D. R.: A new time-of-flight aerosol mass spectrometer (TOF-AMS) - Instrument description and first field deployment, Aerosol Sci. Technol., 39, 637-658, 2005.

Dusek, U., Covert, D. S., Wiedensohler, A., Neususs, C., Weise, D., and Cantrell, W.: Cloud condensation nuclei spectra derived from size distributions and hygroscopic properties of the aerosol in coastal south-west Portugal during ACE-2, Tellus B, 55, 3553, 2003.

Dusek, U., Frank, G. P., Hildebrandt, L., Curtius, J., Schneider, J., Walter, S., Chand, D., Drewnick, F., Hings, S., Jung, D., Borrmann, S., and Andreae, M. O.: Size matters more than chemistry for cloud-nucleating ability of aerosol particles, Science, 312, 1375-1378, 2006a.

Dusek, U., Reischl, G. P., and Hitzenberger, R.: CCN activation of pure and coated carbon black particles, Environ. Sci. Technol., 40, 1223-1230, 2006b.

Ervens, B., Feingold, G., and Kreidenweis, S.: Influence of watersoluble organic carbon on cloud drop number concentration., J. Geophys. Res., 110, D18211, doi:10.1029/2004JD005634, 2005.

Ervens, B., Cubison, M. J., Andrews, E., Feingold, G., Ogren, J. A., Jimenez, J. L., DeCarlo, P., and Nenes, A.: Prediction 
of CCN number concentration using Measurements of Aerosol Size Distributions and Composition and Light Scattering Enhancement Due to Humidity, J. Geophys. Res., 112, D10S32, doi:10.1029/2006JD007426, 2007.

Feingold, G., Boers, R., Stevens, B., and Cotton, W. R.: A modeling study of the effect of drizzle on cloud optical depth and susceptibility, J. Geophys. Res., 102, 13 527-13 534, doi:10.1029/97JD00963, 1997.

Feingold, G.: Modeling of the first indirect effect: Analysis of measurement requirements, Geophys. Res. Lett., 30(19), 1997, doi:10.1029/2003GL017967, 2003.

Gasparini, R., Collins, D. R., Andrews, E., Sheridan, P. J., Ogren, J. A., and Hudson, J. G.: Coupling aerosol size distributions and size-resolved hygroscopicity to predict humidity-dependent optical properties and cloud condensation nuclei spectra., J. Geophys. Res., 111, D05S13, doi:10.1029/2005JD006092, 2006.

Geller, M., Biswas, S., and Sioutas, C.: Determination of particle effective density in urban environments with a differential mobility analyzer and aerosol particle mass analyzer, Aerosol Sci. Technol., 40, 709-723, doi:10.1080/02786820600803925, 2006.

Harley, R. A., Marr, L. C., Lehner, J. K., and Giddings, S. N.: Changes in motor vehicle emissions on diurnal to decadal time scales and effects on atmospheric composition, Environ. Sci. Technol., 39, 5356-5362, 2005.

Hartz, K. E. H., Tischuk, J. E., Chan, M. N., Chan, C. K., Donahue, N. M., and Pandis, S. N.: Cloud condensation nuclei activation of limited solubility organic aerosol, Atmos. Environ., 40, 605617, 2006.

Hudson, J.: Variability of the relationship between particle size and cloud-nucleating ability, Geophys. Res. Lett., 34, L08801, doi:10.1029/2006GL028850, 2007.

IPCC: Climate change 2001: Scientific basis, Third assessment of the Inter-governmental Panel on Climate Change, Cambridge Univ. Press, New York, 2001.

IPCC: Climate change 2007: Scientific basis, Fourth assessment of the Inter-governmental Panel on Climate Change, Cambridge Univ. Press, New York, 2007.

Koehler, K. A., Kreidenweis, S. M., DeMott, P. J., Prenni, A. J., Carrico, C. M., Ervens, B., and Feingold, G.: Water activity and activation diameters from hygroscopicity data - Part II: Application to organic species, Atmos. Chem. Phys., 6, 795-809, 2006, http://www.atmos-chem-phys.net/6/795/2006/.

Kuwata, M., Kondo, Y., Mochida, M., Takegawa, N., and Kawamura, K.: Dependence of CCN activity of less volatile particles on the amount of coating observed in Tokyo, J. Geophys. Res., 112, D11207, doi:10.1029/2006JD007758, 2007.

Lance, S., Medina, J., Smith, J. N., and Nenes, A.: Mapping the operation of the DMT Continuous Flow CCN counter, Aerosol Sci. Technol., 40, 242-254, 2006.

Lanz, V. A., Alfarra, M. R., Baltensperger, U., Buchmann, B., Hueglin, C., and Prevot, A. S. H.: Source Apportionment of Submicron Organic Aerosols at an Urban Site by Factor Analytical Modelling of Aerosol Mass Spectra, Atmos. Chem. Phys., 7, 1503-1522, 2007, http://www.atmos-chem-phys.net/7/1503/2007/.

Lee, S. H., Murphy, D. M., Thomson, D. S., and Middlebrook, A. M.: Chemical components of single particles measured with Particle Analysis by Laser Mass Spectrometry (PALMS) during the Atlanta SuperSite Project: Focus on organic/sulfate, lead, soot, and mineral particles, J. Geophys. Res., 107, 4003, doi:10.1029/2000JD000011, 2002.

Lee, S. H., Murphy, D. M., Thomson, D. S., and Middlebrook, A. M.: Nitrate and oxidized organic ions in single particle mass spectra during the 1999 Atlanta Supersite Project, J. Geophys. Res., 108, 8417, doi:10.1029/2001JD001455, 2003.

Lee, Y. S., Collins, D. R., Li, R. J., Bowman, K. P., and Feingold, G.: Expected impact of an aged biomass burning aerosol on cloud condensation nuclei and cloud droplet concentrations, J. Geophys. Res., 111, D22204, doi:10.1029/2005JD006464, 2006.

Liu, Y. G. and Daum, P. H.: Anthropogenic aerosols - Indirect warming effect from dispersion forcing, Nature, 419, 580-581, 2002.

Lough, G. C., Schauer, J. J., and Lawson, D. R.: Day-of-week trends in carbonaceous aerosol composition in the urban atmosphere, Atmos. Environ., 40, 4137-4149, 2006.

McFiggans, G., Alfarra, M. R., Allan, J., Bower, K. N., Coe, H., Cubison, M., Topping, D., Williams, P. I., Decesari, S., Facchini, C., and Fuzzi, S.: Simplification of the representation of the organic component of atmospheric particulates, Faraday Discuss., 130, 341-362, doi:10.1039/b419435g, 2005.

McMurry, P. H., Litchy, M., Huang, P.-F., Cai, X., Turpin, B. J., Dick, W. D., and Hanson, A.: Elemental composition and morphology of individual particles separated by size and hygroscopicity with the TDMA, Atmos. Environ., 30, 101-108, 1996.

McMurry, P. H., Wang, X., Park, K., and Ehara, E.: The Relationship Between Mass and Mobility for Atmospheric Particles: A New Technique for Measuring Particle Density, Aerosol Sci. Technol., 36, 227-238, 2002.

Medina, J., Nenes, A., Sotiropoulou, R. E. P., Cottrell, L. D., Ziemba, L. D., Beckman, P. J., and Griffin, R. J.: Cloud Condensation Nuclei (CCN) closure during the ICARTT 2004 campaign: a) effects of size-resolved composition, J. Geophys. Res., 112, D10S31, doi:10.1029/2006JD007588, 2007.

Middlebrook, A., Murphy, D. M., Lee, S.-H., Thomson, D. S., Prather, K. A., Wenzel, R. J., Liu, D.-Y., Phares, D. J., Rhoads, K. P., Wexler, A. S., Johnston, M. V., Jimenez, J. L., Jayne, J. T., Worsnop, D. R., Yourshaw, I., Seinfeld, J. H., and Flagan, R. C.: A Comparison of Particle Mass Spectrometers During the 1999 Atlanta Supersite Project, J. Geophys. Res., 108, 8424, doi:10.1029/2001JD000660, 2003.

Mircea, M., Facchini, M. C., Decesari, S., Cavalli, F., Emblico, L., Fuzzi, S., Vestin, A., Rissler, J., Swietlicki, E., Frank, G., Andreae, M. O., Maenhaut, W., Rudich, Y., and Artaxo, P.: Importance of the organic aerosol fraction for modeling aerosol hygroscopic growth and activation: a case study in the Amazon Basin, Atmos. Chem. Phys., 5, 3111-3126, 2005,

http://www.atmos-chem-phys.net/5/3111/2005/.

Mochida, M., Kuwata, M., Miyakawa, T., Takegawa, N., Kawamura, K., and Kondo, Y.: Relationship between hygroscopicity and cloud condensation nuclei activity for urban aerosols in Tokyo., J. Geophys. Res., 111, D23204, doi:10.1029/2005JD006980, 2006.

Molina, L. T., Kolb, C. E., de Foy, B., Lamb, B. K., Brune, W. H., Jimenez, J. L., and Molina, M. J.: Air Quality in North America's Most Populous City - Overview of MCMA-2003 Campaign, Atmos. Chem. Phys., 7, 2447-2473, 2007, http://www.atmos-chem-phys.net/7/2447/2007/.

Murphy, D. M., Cziczo, D. J., Froyd, K. D., Hudson, P. K., Matthew, 
B. M., Middlebrook, A. M., Peltier, R. E., Sullivan, A., Thomson, D. S., and Weber, R. J.: Single-particle mass spectrometry of tropospheric aerosol particles, J. Geophys. Res., 111, D23S32, doi:10.1029/2006JD007340, 2006.

Niemi, J. V., Saarikoski, S., Tervahattu, H., Makela, T., Hillamo, R., Vehkamaki, H., Sogacheva, L., and Kulmala, M.: Changes in background aerosol composition in Finland during polluted and clean periods studied by TEM/EDX individual particle analysis, Atmos. Chem. Phys., 6, 5049-5066, 2006,

http://www.atmos-chem-phys.net/6/5049/2006/.

Noble, C. A. and Prather, K. A.: Real-time measurement of correlated size and composition profiles of individual atmospheric aerosol particles, Environ. Sci. Technol., 30, 2667-2680, 1996.

Petters, M. D., Prenni, A. J., Kreidenweis, S. M., DeMott, P. J., Matsunaga, A., Lim, Y. B., and Ziemann, P. J.: Chemical aging and the hydrophobic-to-hydrophilic conversion of carbonaceous aerosol, Geophys. Res. Lett., 33, L24806, doi:10.1029/2006GL027249, 2006.

Petters, M. D. and Kreidenweis, S.: A single parameter representation of hygroscopic growth and cloud condensation nucleus activity, Atmos. Chem. Phys., 7, 1961-1971, 2007,

http://www.atmos-chem-phys.net/7/1961/2007/.

Prenni, A. J., Petters, M. D., Kreidenweis, S. M., DeMott, P. J., and Ziemann, P. J.: Cloud droplet activation of secondary organic aerosol, J. Geophys. Res., 112, D10223, doi:10.1029/2006JD007963, 2007.

Quinn, P. K., Bates, T. S., Coffman, D. J., and Covert, D. S.: Influence of particle size and chemistry on the cloud nucleating properties of aerosols, Atmos. Chem. Phys., 8, 1029-1042, 2008,

http://www.atmos-chem-phys.net/8/1029/2008/.

Raymond, T. M. and Pandis, S. N.: Cloud activation of singlecomponent organic aerosol particles, J. Geophys. Res., 107, 4787, doi:10.1029/2002JD002159, 2002.

Riemer, N., Vogel, H., and Vogel, B.: Soot aging time scales in polluted regions during day and night, Atmos. Chem. Phys., 4, 1885-1893, 2004, http://www.atmos-chem-phys.net/4/1885/2004/.

Rissler, J., Swietlicki, E., Zhou, J., Roberts, G., Andreae, M. O., Gatti, L. V., and Artaxo, P.: Physical properties of the submicrometer aerosol over the Amazon rain forest during the wetto-dry season transition - comparison of modeled and measured CCN concentrations, Atmos. Chem. Phys., 4, 2119-2143, 2004, http://www.atmos-chem-phys.net/4/2119/2004/.

Roberts, G., Mauger, G., Hadley, O., and Ramanathan, V.: North American and Asian aerosols over the eastern Pacific Ocean and their role in regulating cloud condensation nuclei, J. Geophys. Res., 111, D13205, doi:10.1029/2005JD006661, 2006.

Roberts, G. C., Artaxo, P., Zhou, J. C., Swietlicki, E., and Andreae, M. O.: Sensitivity of CCN spectra on chemical and physical properties of aerosol: A case study from the Amazon Basin, J. Geophys. Res., 107, 8070, doi:10.1029/2001JD000583, 2002.

Roberts, G. C., Nenes, A., Seinfeld, J. H., and Andreae, M. O.: Impact of biomass burning on cloud properties in the Amazon Basin, J. Geophys. Res., 108, 4062, doi:10.1029/2001JD000985, 2003.

Roberts, G. C. and Nenes, A.: A continuous-flow streamwise thermal-gradient $\mathrm{CCN}$ chamber for atmospheric measurements, Aerosol Sci. Technol., 39, 206-221, 2005.

Rose, D., Gunthe, S. S., Mikhailov, E., Frank, G. P., Dusek, U.,
Andreae, M. O., and Poschl, U.: Calibration and measurement uncertainties of a continuous-flow cloud condensation nuclei counter (DMT-CCNC): CCN activation of ammonium sulfate and sodium chloride aerosol particles in theory and experiment, Atmos. Chem. Phys., 8, 1153-1179, 2008,

http://www.atmos-chem-phys.net/8/1153/2008/.

Ruehl, C. R., Chuang, P. Y., and Nenes, A.: How quickly do cloud droplets form on atmospheric particles?, Atmos. Chem. Phys., 8, 1043-1055, 2008,

http://www.atmos-chem-phys.net/8/1043/2008/.

Salcedo, D., Onasch, T. B., Dzepina, K., Canagaratna, M. R., Zhang, Q., Huffman, J. A., DeCarlo, P. F., Jayne, J. T., Mortimer, P., Worsnop, D. R., Kolb, C. E., Johnson, K. S., Zuberi, B., Marr, L. C., Volkamer, R., Molina, L. T., Molina, M. J., Cardenas, B., Bernabe, R. M., Marquez, C., Gaffney, J. S., Marley, N. A., Laskin, A., Shutthanandan, V., Xie, Y., Brune, W., Lesher, R., Shirley, T., and Jimenez, J. L.: Characterization of ambient aerosols in Mexico City during the MCMA-2003 campaign with Aerosol Mass Spectrometry: results from the CENICA Supersite, Atmos. Chem. Phys., 6, 925-946, 2006,

http://www.atmos-chem-phys.net/6/925/2006/.

Slowik, J. G., Stainken, K., Davidovits, P., Williams, L. R., Jayne, J. T., Kolb, C. E., Worsnop, D. R., Rudich, Y., DeCarlo, P. F., and Jimenez, J. L.: Particle morphology and density characterization by combined mobility and aerodynamic diameter measurements, Part 2: Application to combustion-generated soot aerosols as a function of fuel equivalence ratio, Aerosol Sci. Technol., 38, 1206-1222, 2004.

Snyder, D. C. and Schauer, J. J.: An Inter-Comparison of Two Black Carbon Aerosol Instruments and a Semi-Continuous Elemental Carbon Instrument in the Urban Environment, Aerosol Sci. Technol., 41, 463-474, 2007.

Sotiropoulou, R. E. P., Medina, J., and Nenes, A.: CCN predictions: Is theory sufficient for assessments of the indirect effect?, Geophys. Res. Lett., 33, L05816, doi:10.1029/2005GL025148, 2006.

Sotiropoulou, R. E. P., Nenes, A., Adams, P. J., and Seinfeld, J. H.: Cloud condensation nuclei prediction error from application of Köhler theory: Importance for the aerosol indirect effect, J. Geophys. Res., 112, D12202, doi:10.1029/2006JD007834, 2007.

Spencer, M. T., Shields, L. G., and Prather, K. A.: Simultaneous Measurement of the Effective Density and Chemical Composition of Ambient Aerosol Particles, Environ. Sci. Technol., 41, 1303-1309, doi:10.1021/es061425, 2007.

Stroud, C. A., Nenes, A., Jimenez, J. L., DeCarlo, P., Huffman, J. A., Bruintjes, R., Nemitz, E., Delia, A. E., Toohey, D. W., Guenther, A. B., and Nandi, S.: Cloud Activating Properties of Aerosol Observed during CELTIC, J. Atmos. Sci., 64, 441-459, 2007.

Svenningsson, I. B., Hansson, H. C., Wiedensohler, A., Ogren, J., Noone, K. J., and Hallberg, A.: Hygroscopic Growth of AerosolParticles in the Po Valley, Tellus, 44B, 556-569, 1992.

Swietlicki, E., Zhou, J., Berg, O. H., Martinsson, B. G., Frank, G., Cederfelt, S., Dusek, U., Berner, A., Birmili, W., Wiedensohler, A., Yuskiewicz, B., and Bower, K. N.: A closure study of submicrometer aerosol particle hygroscopic behaviour, Atmos. Res., 50, 205-240, 1999.

Textor, C., Schulz, M., Guibert, S., Kinne, S., Balkanski, Y., Bauer, S., Berntsen, T., Berglen, T., Boucher, O., Chin, M., Dentener, 
F., Diehl, T., Easter, R., Feichter, H., Fillmore, D., Ghan, S., Ginoux, P., Gong, S., Kristjansson, J. E., Krol, M., Lauer, A., Lamarque, J. F., Liu, X., Montanaro, V., Myhre, G., Penner, J., Pitari, G., Reddy, S., Seland, O., Stier, P., Takemura, T., and Tie, X.: Analysis and quantification of the diversities of aerosol life cycles within AeroCom, Atmos. Chem. Phys., 6, 1777-1813, 2006, http://www.atmos-chem-phys.net/6/1777/2006/.

Tolocka, M. P., Lake, D. A., Johnston, M. V., and Wexler, A. S.: Size-resolved fine and ultrafine particle composition in Baltimore, Maryland, J. Geophys. Res., 110, D07S04, doi:10.1029/2004JD004573, 2005.

Twomey, S.: Pollution and planetary albedo, Atmos. Environ., 8, 1251-1256, 1974.

Twomey, S.: Aerosols, Clouds and Radiation, Atmos Environ., 25, 2435-2442, 1991.

Twomey, S. A.: The influence of pollution on the shortwave albedo of clouds., J. Atmos. Sci., 34, 1148-1152, 1977.

Ulbrich, I.: Source apportionment of AMS data in Pittsburgh, Mexico City, and Houston by PMF, Eos Trans. AGU, 87, Fall Meet. Suppl., Abstract A23C-0980, 2006.

Ulbrich, I. M., Canagaratna, M. R., Zhang, Q., Worsnop, D. R., and Jimenez, J. L.: Interpretation of Organic Components from Positive Matrix Factorization of Aerosol Mass Spectrometric Data, Atmos. Chem. Phys. Discuss., 8, 6729-6791, 2008, http://www.atmos-chem-phys-discuss.net/8/6729/2008/.

VanReken, T. M., Rissman, T. A., Roberts, G. C., Varutbangkul, V., Jonsson, H. H., Flagan, R. C., and Seinfeld, J. H.: Toward aerosol/cloud condensation nuclei (CCN) closure during CRYSTAL-FACE, J. Geophys. Res., 108, 4633, doi:10.1029/2003JD003582, 2003.

VanReken, T. M., Ng, N. L., Flagan, R. C., and Seinfeld, J. H.: Cloud condensation nucleus activation properties of biogenic secondary organic aerosol, J. Geophys. Res., 110, D07206, doi:10.1029/2004JD005465, 2005.

Varutbangkul, V., Brechtel, F. J., Bahreini, R., Ng, N. L., Keywood, M. D., Kroll, J. H., Flagan, R. C., Seinfeld, J. H., Lee, A., and Goldstein, A. H.: Hygroscopicity of secondary organic aerosols formed by oxidation of cycloalkenes, monoterpenes, sesquiterpenes, and related compounds, Atmos. Chem. Phys., 6, 23672388, 2006, http://www.atmos-chem-phys.net/6/2367/2006/.

Volkamer, R., Jimenez, J. L., Martini, F. S., Dzepina, K., Zhang, Q., Salcedo, D., Molina, L. T., Worsnop, D. R., and Molina., M. J.: Secondary Organic Aerosol Formation from Anthropogenic Air Pollution: Rapid and Higher than Expected., Geophys. Res. Lett., 33, L17811, doi:10.1029/2006GL026899, 2006.
Wang, J. and Martin, S. T.: Satellite characterization of urban aerosols: Importance of including hygroscopicity and mixing state in the retrieval algorithms, J. Geophys. Res., 112, D17203, doi:10.1029/2006JD008078, 2007.

Warner, J.: Microstructure of Cumulus Cloud .2. Effect on Droplet Size Distribution of Cloud Nucleus Spectrum and Updraft Velocity, J. Atmos. Sci., 26, 1272-1282, 1969.

Weingartner, E., Burtscher, H., and Baltensperger, U.: Hygroscopic properties of carbon and diesel soot particles., Atmos. Environ., 31, 2311-2327, 1997.

Zhang, Q., Stanier, C. O., Canagaratna, M. C., Jayne, J. T., Worsnop, D. R., Pandis, S. N., and Jimenez, J. L.: Insights into the Chemistry of New Particle Formation and Growth Events in Pittsburgh Based on Aerosol Mass Spectrometry, Environ. Sci. Technol., 38, 4797-4809, 2004a.

Zhang, X., Smith, K. A., Worsnop, D. R., Jimenez, J. L., Jayne, J. T., Kolb, C. E., Morris, J., and Davidovits, P.: Characterization of Particle Beam Collimation: Part II Integrated Aerodynamic Lens-Nozzle System, Aerosol Sci. Technol., 38, 619-638, 2004 b.

Zhang, Q., Alfarra, M. R., Worsnop, D. R., Allan, J. D., Coe, H., Canagaratna, M. R., and Jimenez, J. L.: Deconvolution and Quantification of Hydrocarbon-Like and Oxygenated Organic Aerosols Based on Aerosol Mass Spectrometry., Environ. Sci. Technol., 39, 4938-4952, 2005a.

Zhang, Q., Canagaratna, M. R., Jayne, J. T., Worsnop, D. R., and Jimenez, J. L.: Time and Size-Resolved Chemical Composition of Submicron Particles in Pittsburgh - Implications for Aerosol Sources and Processes., J. Geophys. Res., 110, D07S09, doi:10.1029/2004JD004649, 2005b.

Zhang, Q., Worsnop, D. R., Canagaratna, M. R., and Jimenez, J. L.: Hydrocarbon-like and oxygenated organic aerosols in Pittsburgh: insights into sources and processes of organic aerosols, Atmos. Chem. Phys., 5, 3289-3311, 2005c, http://www.atmos-chem-phys.net/5/3289/2005/.

Zhang, Q., Jimenez, J. L., Canagaratna, M. R., Allan, J. D., Coe, H., Ulbrich, I., Alfarra, M. R., Takami, A., Middlebrook, A. M., Sun, Y. L., Dzepina, K., Dunlea, E., Docherty, K., DeCarlo, P. F., Salcedo, D., Onasch, T., Jayne, J. T., Miyoshi, T., Shimono, A., Hatakeyama, S., Takegawa, N., Kondo, Y., Schneider, J., Drewnick, F., Weimer, S., Demerjian, K., Williams, P., Bower, K., Bahreini, R., Cottrell, L., Griffin, R. J., Rautiainen, J., and Worsnop., D. R.: Ubiquity and Dominance of Oxygenated Species in Organic Aerosols in Anthropogenically-Influenced Northern Hemisphere Mid-latitudes, Geophys. Res. Lett., 34, L13801, doi:10.1029/2007GL029979, 2007. 